\title{
Trace elements and cathodoluminescence of quartz in stockwork veins of Mongolian porphyry-style deposits
}

\author{
Axel Müller • Richard Herrington • Robin Armstrong • \\ Reimar Seltmann • Douglas J. Kirwin • \\ Nina G. Stenina $\cdot$ Andreas Kronz
}

Received: 27 September 2009 / Accepted: 15 June 2010 / Published online: 29 July 2010

(C) Springer-Verlag 2010

\begin{abstract}
The combination of scanning electron microscope-cathodoluminescence (CL), fluid inclusion analysis and high-resolution electron probe microanalysis of $\mathrm{Al}, \mathrm{Ti}$, $\mathrm{K}$ and $\mathrm{Fe}$ in vein quartz has yielded results permitting a greater understanding of the complex mineralisation of the Central Oyu Tolgoi and Zesen Uul porphyry-style deposits, southern Mongolia. These data demonstrate the relationship between quartz precipitation, dissolution and ore deposition as the mineralising fluid chemistry changed through time. Four major quartz generations are identified in the A-type veins from the stockworks of both the
\end{abstract}

Editorial handling: B. Lehmann

A. Müller $(\bowtie)$

Department of Mineral Resources, Geological Survey of Norway,

7491 Trondheim, Norway

e-mail: Axel.Muller@ngu.no

R. Herrington $\cdot$ R. Armstrong $\cdot$ R. Seltmann

Department of Mineralogy, CERCAMS,

Natural History Museum,

Cromwell Road,

London SW7 5BD, UK

\section{J. Kirwin}

Ivanhoe Mines,

51/278 Muang Ake, Tambon Lak 6, Amphoe Muang,

Pathumthanee,

Bangkok 12000, Thailand

N. G. Stenina

Institute of Geology and Mineralogy SB RAS,

Koptuyga prosp. 3,

Novosibirsk 630090, Russia

\section{A. Kronz}

Geowissenschaftliches Zentrum Göttingen,

Goldschmidtstr. 1,

37077 Göttingen, Germany
Central Oyu Tolgoi (OTi to OTiv) and Zesen Uul deposits (ZUi to ZUiv). Despite differences in the associated alteration and mineralisation style, the observed $\mathrm{CL}$ textures and trace element signatures of the quartz generations are comparable between deposits. The OTi and ZUi stage formed both the primary network of A-type veins and pervasive silicification of the host rock. Using the Ti-in-quartz geothermometer, crystallisation temperatures for $\mathrm{OTi}$ and $\mathrm{ZUi}$ of between $598^{\circ} \mathrm{C}$ and $880^{\circ} \mathrm{C}$ are indicated. The main stage of sulphide mineralisation was accompanied by the dissolution of pre-existing quartz (OTi and ZUi) and precipitation of a weakly luminescent generation of quartz (OTii and ZUii) with a low Ti content, reflected in a calculated temperature drop from approximately $700^{\circ} \mathrm{C}$ to $340^{\circ} \mathrm{C}$ in Central Oyu Tolgoi and $445^{\circ} \mathrm{C}$ in Zesen Uul. OTii and ZUii stage quartzes show high and variable $\mathrm{Al}$ concentrations. The next stage of quartz in both deposits (OTiii and ZUiii) forms a fine network of veins in cracks formed in pre-existing quartz. OTiii and ZUiii quartz contain measurable fluid inclusions of moderate salinity (3-17.1 wt.\% $\mathrm{NaCl}$ eq.), entrapped in the temperature range $256^{\circ} \mathrm{C}$ to $385^{\circ} \mathrm{C}$. OTiii and ZUiii are not related to any sulphide mineralisation. The final OTiv and ZUiv stages are characterised by quartz-calcite micro-breccias that penetrate the A-type veins. Based on the calculated entrapment temperatures, the OTiv/ZUiv stage crystallised between $212^{\circ} \mathrm{C}$ and $335^{\circ} \mathrm{C}$, and the quartz is characterised by elevated but variable $\mathrm{Al}$ and $\mathrm{Fe}$ contents. The $\mathrm{CL}$ and trace element signatures of the OTi to OTiii and ZUi to ZUiii stages of the two Mongolian porphyries show similar features to those observed in porphyry-style deposits from other regions. This suggests that a common sequence of quartz crystallisation occurs during the formation of early veins in many porphyry copper systems. 
Keywords Copper porphyry · Quartz .

Cathodoluminescence · Fluid inclusion · Trace elements . Mongolia

\section{Introduction}

Hypogene porphyry-style mineralisation is characterised by stockwork-hosted and disseminated sulphides that are temporally and spatially related to the shallow $(2-5 \mathrm{~km})$ emplacement of magmas of intermediate to acidic composition. The complexity of quartz veining in porphyry-style deposit stockworks arises from the repeated precipitation and dissolution of quartz formed from episodically exsolved magmatic volatile phases (MVP) derived from subvolcanic intrusions (e.g. Hedenquist and Lowenstern 1994; Bodnar 1995; Candela and Piccoli 1995; Harris and Golding 2002). Porphyry systems are typified by multiple stages of intrusion accompanied by numerous episodes of MVP exsolution, resulting in repeated overprinting mineralising events formed under differing physicochemical conditions (e.g. Guilbert and Lowell 1974; Carten et al. 1988; Fournier 1999; Proffett 2003; Harris et al. 2003; Seedorff et al. 2005). One result of this is a complex succession of quartz crystallisation, deformation and healing observed in the stockwork zones. In order to better classify the spatial and temporal relationships of stockwork veining and associated alteration, Gustafson and Hunt (1975) introduced classes of veins termed A (early), B (transitional) and D (late) stage. The scheme was extended by Dilles and Einaudi (1992) to include a late C-type vein and by Arancibia and Clark (1996) to include an early M-type vein. Early A-veins are defined as irregular (wispy-looking), discontinuous and segmented veins of quartz \pm bornite \pm chalcopyrite \pm anhydrite associated with a potassic alteration assemblage of Kfeldspar and biotite (Gustafson and Hunt 1975). However, recent studies revealed that A-veins are commonly multigenerational with superimposed quartz generations that can be related to B, C and D type events (e.g. Rusk and Reed 2002; Müller et al. 2003; Rusk et al. 2006, 2008a).

The aim of the study is to better understand the evolutionary sequence of quartz crystallisation associated mineralisations of A-type and other associated veins of the late Devonian Central Oyu Tolgoi and early Carboniferous Zesen Uul porphyry copper deposits in the south Gobi region of Mongolia (Figs. 1 and 2). There classic A-type veins are developed in porphyry stockworks, but they have been overprinted by multiple syn- and post-mineralisation events.

Cathodoluminescence (CL) imaging was used to establish quartz generations and relative chronology. Electron probe microanalysis (EPMA) was then used to determine quartz trace element chemistry (specifically $\mathrm{Al}, \mathrm{K}$, Ti and
$\mathrm{Fe}$ ). The variation in the distributions of these trace elements in quartz reflects changes in the P-T-X conditions of the quartz-depositing fluids (e.g. Wark and Watson 2006; Rusk et al. 2006, 2008a); thus, a systematic analysis of trace element contents can be used to interpret conditions of crystal growth. The use of backscattered electron (BSE) imaging helped to establish the paragenetic relationships between ore mineral assemblages and different quartz generations. Finally, fluid inclusion microthermometry was carried out on recognized quartz generations. The occurrence of fine-grained ore mineral inclusions within the quartz was also able to provide direct evidence for the genetic relationship between ore minerals and quartz (Wilkinson 2001).

This use of combined methods was essential because preserved and measurable fluid inclusions are rare in the veins. The rarity of measurable fluid inclusions is presumed to be due to the age of the two investigated Mongolian porphyries (ca. 370 and $330 \mathrm{Ma}$, respectively; Seltmann and Porter 2005) as the entire rock package has suffered intense regional post-mineralisation folding (Wainwright et al. 2004). However, a few notable, well-preserved fluid inclusions were measured and these supplied supporting evidence for the precipitation temperatures of the late quartz generations.

\section{Geology of deposits}

The Central Oyu Tolgoi and Zesen Uul deposits are located respectively 600 and $500 \mathrm{~km}$ south of Ulaan Baatar. Both deposits are hosted in the Gurvansayhan Terrane (Fig. 1), which is located in the central-southern section of the Kazakh-Mongol magmatic arc where it trends roughly east-west (Gerel 1995, 1998; Jargalsaihan 1996; Badarch et al. 2002; Fig. 1). The geology of the $600 \times 200-\mathrm{km}$ triangular-shaped terrane is dominated by Silurian to Carboniferous clastic sedimentary rocks, carbonates, volcaniclastic sedimentary rocks and intermediate to felsic volcanic rocks. This sequence is cut by a suite of Devonian granitoids and by Permo-Carboniferous diorite, monzodiorite, granite, granodiorite and syenite bodies. The Permo-Carboniferous intrusions range in size from narrow dykes to batholiths that are tens of kilometres across (Perelló et al. 2001; Badarch et al. 2002). The original architecture of the sequence and the magmatic arc have been disrupted by later intrusive masses, modified by both mid- to late Palaeozoic accretion and Mesozoic thrust and sinistral strike-slip faulting and lastly masked by alluvium deposited on a mature erosional surface. This has resulted in the current outcrop pattern of a complex sequence of imbricate thrust sheets, dismembered blocks and high strain zones (Badarch et al. 2002). 


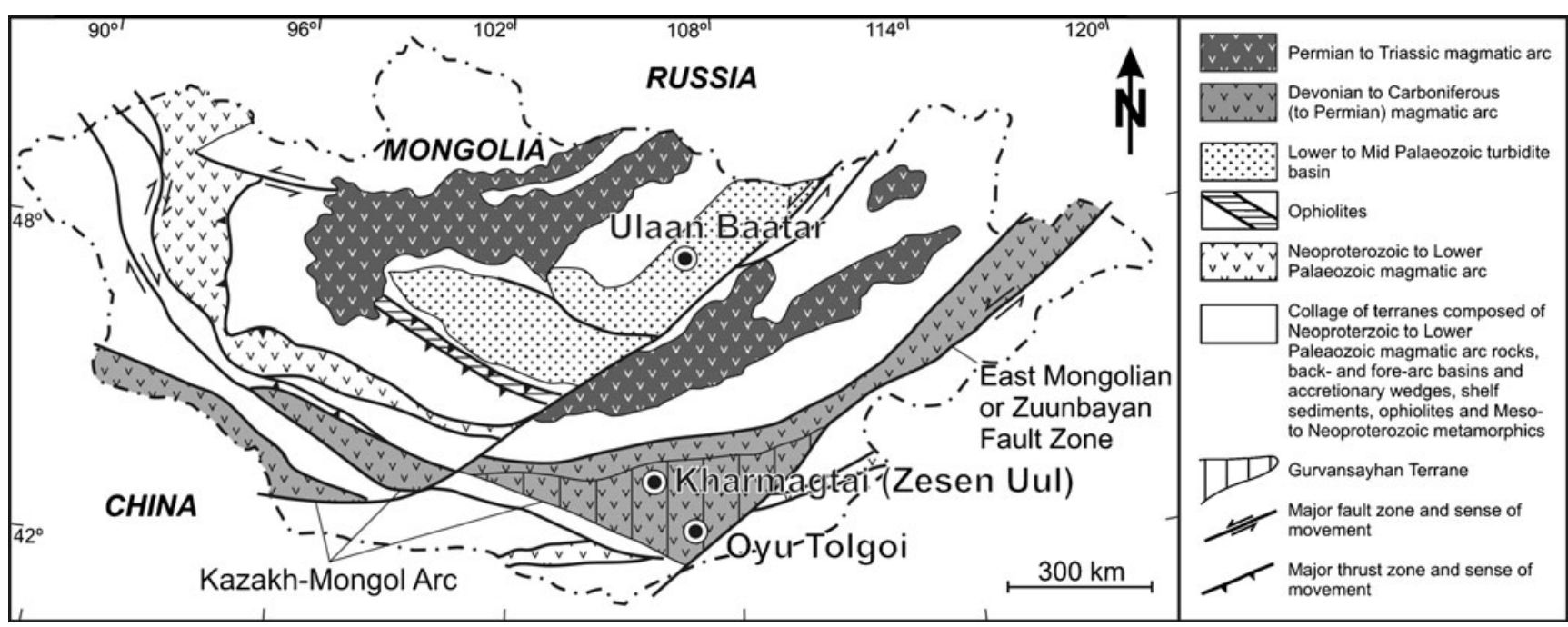

Fig. 1 Tectonic map of Mongolia showing the locations of the Oyu Tolgoi and Zesen Uul porphyry deposits in the Gobi desert (modified after Badarch et al. 2002, Kirwin et al. 2005a and Seltmann and Porter 2005)

\section{Central Oyu Tolgoi}

The Central Oyu Tolgoi deposit is one of four discrete mineralised zones in the Oyu Tolgoi exploration area, which are interpreted to constitute four separate porphyry copper centres (Forster et al. 2003; Kirwin et al. 2003,

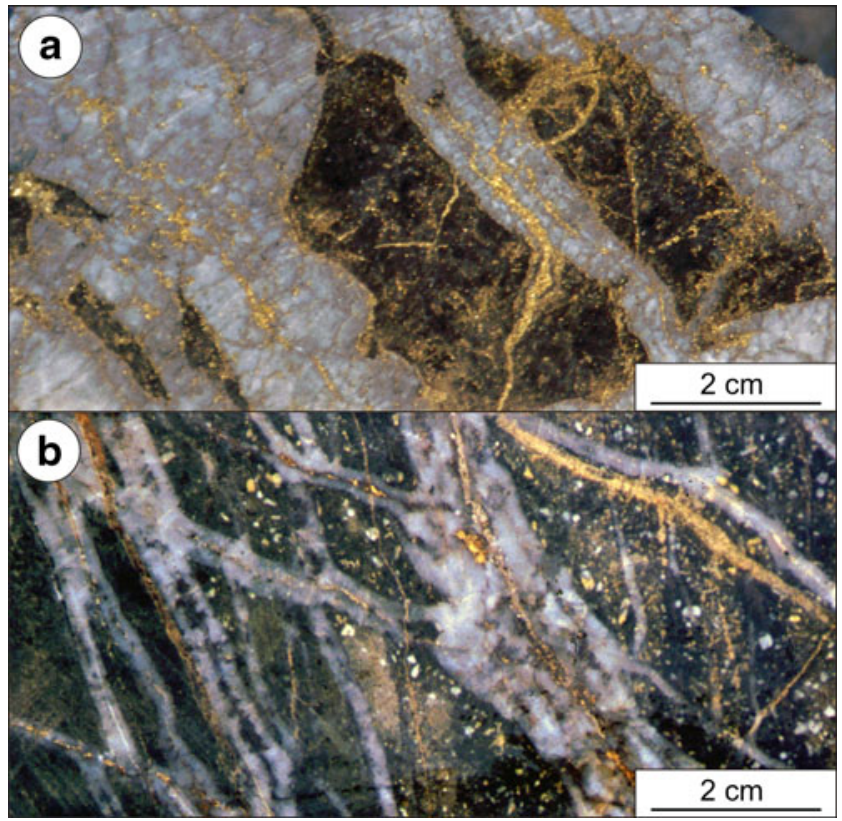

Fig. 2 a Photograph of A-type quartz veins from the central stockwork of the central Oyu Tolgoi porphyry deposit. The sulphide veinlets and impregnations consist of pyrite and chalcopyrite. The igneous host rock shows silicification and strong biotite alteration. b Photograph of A-type quartz veins from the central stockwork of the Zesen Uul porphyry deposit. Sulphide veinlets comprising pyrite, chalcopyrite and magnetite occur in the centre of or parallel to quartz veins. The host rock was affected by strong silicification, chloritisation and albitisation 2005a; Khashgerel et al. 2008; Fig. 3a). These mineralised centres formed at $370 \mathrm{Ma}$ and are among the largest and richest known hypogene $\mathrm{Cu}-\mathrm{Au}$ deposits in the world. The geology at Central Oyu Tolgoi is dominated by a SilurianDevonian sequence of andesitic and basaltic lavas interbedded with fine- to coarse-grained, volcaniclastic sedimentary rocks (Perelló et al. 2001). The tentative hard rock stratigraphy is, from youngest to oldest: (1) dacite flow units, (2) basaltic tuff and flow units, (3) upper sedimentary sequence, (4) lower sedimentary sequence, (5) dacitic pyroclastic units, (6) augite basalt flow and related breccias and (7) andesitic volcaniclastic units (Ivanhoe Mines 2008). The sequence is crosscut by variably altered and mineralised porphyritic quartz monzodiorite dykes that are genetically related to the $\mathrm{Cu}-\mathrm{Au}$ porphyry systems (Ivanhoe Mines 2008). Postmineralisation syenitic granitoids and dykes of basalt, rhyolite and hornblende-biotite andesite occur throughout the district.

The Central Oyu Tolgoi deposit comprises a high sulphidation system developed above and partly telescoped onto an underlying centre of porphyry mineralisation (Fig. 3b). It consists of a multi-phase hydrothermal breccia crosscutting an altered fine-grained quartz monzodiorite with porphyry-type alteration and mineralisation (Perelló et al. 2001). Covellite and pyrite are developed within an upwardly flared zone of intense quartz-muscovite alteration with subordinate alunite, dickite and pyrophyllite (advanced argillic alteration; Forster et al. 2003). In addition, a supergene enriched chalcocite blanket and copper oxide mineralisation some $20-60 \mathrm{~m}$ thick is present at depths varying from near surface to $150 \mathrm{~m}$, which has been superimposed on the high sulphidation covellite-pyrite mineralisation (Ivanhoe Mines 2008). The chalcocite blanket occupies an area 1,300×600 m (Perelló 

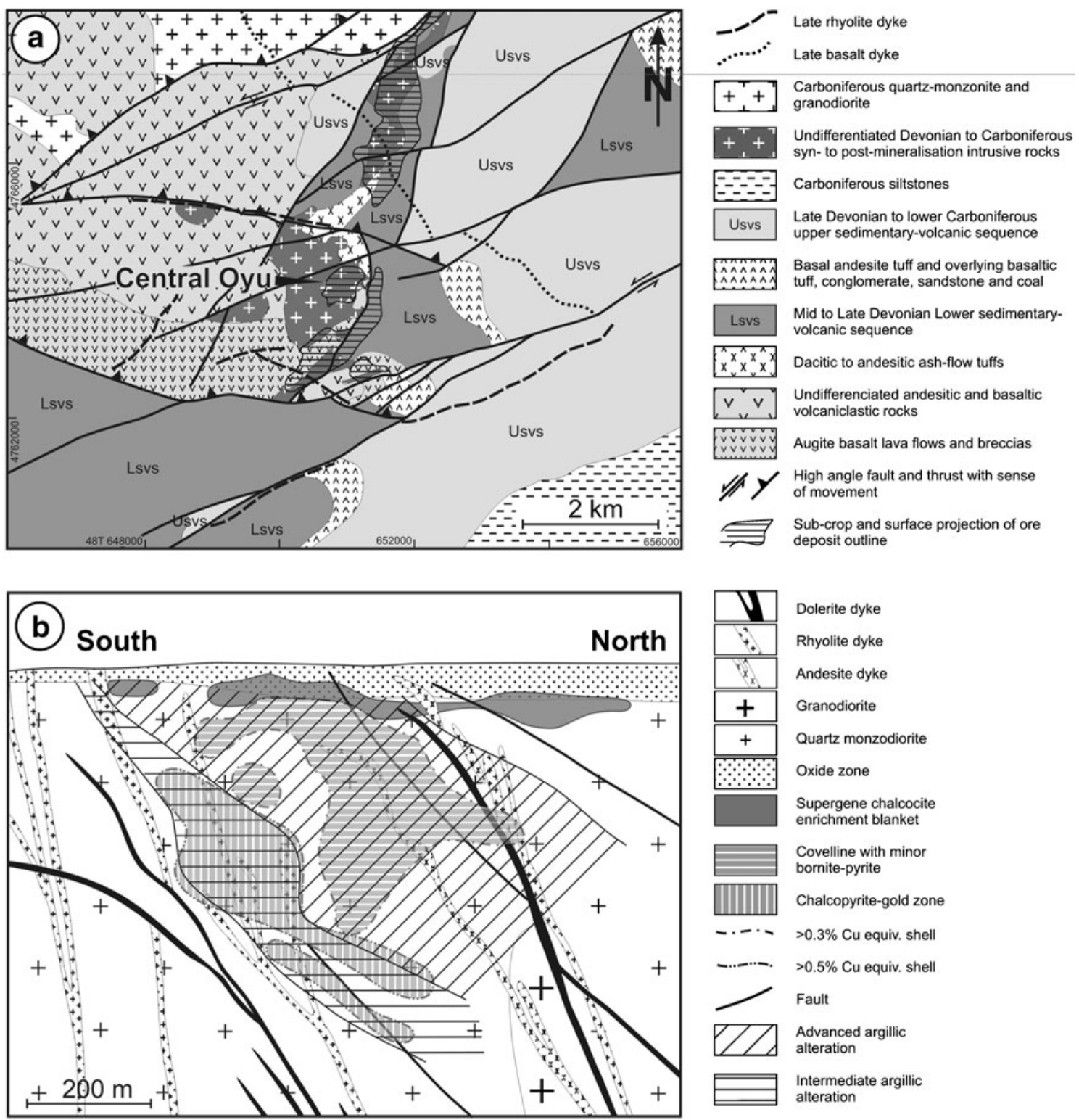

Fig. 3 a District scale geological setting of the Oyu Tolgoi porphyry $\mathrm{Cu}-\mathrm{Au}$ deposits. b Geological cross section through the Central Oyu Tolgoi porphyry system (modified after Kirwin et al. 2005a and Ivanhoe Mines 2008)

et al. 2001). The covellite-pyrite zone below the blanket has a horizontal extent of about 400 by $450 \mathrm{~m}$ and a thickness of about $350 \mathrm{~m}$. A chalcopyrite-gold mineralisation assemblage is developed in the intermediate argillic alteration zone between 150 and $700 \mathrm{~m}$ depth, partially enveloping and below the covellite-pyrite zone (Fig. 3b).

Drill core samples from Central Oyu Tolgoi were examined from the chalcopyrite-gold zone of the porphyry copper deposits, from depths varying between 210 and $580 \mathrm{~m}$ below the supergene chalcocite blanket developed over the hypogene mineralisation. The samples contain predominantly irregular, wormy and wispy A-type and other associated quartz veinlets with biotite, pyrophyllite, pyrite, chalcopyrite and molybdenite embedded in strongly silicified and altered host rock of magmatic origin (Figs. 2 and 4). Vein densities of the samples exceed $100 / \mathrm{m}^{2}$. The shape of these veins indicates that they formed under ductile conditions at high temperatures during periods of high strain rates (e.g. Fournier 1999). All Central Oyu Tolgoi samples contain pyrophyllite as a gangue mineral; it replaces biotite and is intergrown with $\mathrm{Al}$-phosphates and alunite. A few late quartz-calcite veinlets crosscut the sulphide assemblages. Crosscutting micro-breccias, which are healed by quartz and calcite, are the last stage of mineralisation, and some of these healed micro-breccias contain fluorite. 


\begin{tabular}{|l|l|c|c|c|}
\hline \multicolumn{5}{|c|}{ Central Oyu Tolgoi } \\
\hline \multicolumn{1}{|c|}{ mineral } & OTi & $\begin{array}{c}\text { OTii } \\
\text { main ore stage }\end{array}$ & OTiii & $\begin{array}{c}\text { OTiv quartz- } \\
\text { carbonate stage }\end{array}$ \\
\hline $\begin{array}{l}\text { OTi quartz } \\
\text { OTii quartz } \\
\text { OTiii quartz } \\
\text { OTiv quartz }\end{array}$ & & & \\
\cline { 1 - 2 } $\begin{array}{l}\text { biotite } \\
\text { pyrite } \\
\text { chalcopyrite } \\
\text { molybdenite } \\
\text { rutile } \\
\text { pyrophyllite } \\
\text { alunite } \\
\text { calcite } \\
\text { apatite } \\
\text { fluorite }\end{array}$ & & & & \\
\hline
\end{tabular}

Fig. 4 Mineral paragenesis and related quartz crystallisation sequence of the central stockwork at Central Oyu Tolgoi observed in the samples studied

\section{Zesen Uul}

Zesen Uul is one of four recognized gold-copper deposits in the Kharmagtai district (Fig. 5a). The Kharmagtai exploration area is characterised by several high-grade, porphyry-hosted (monzodiorite) gold and copper mineral deposits similar in style to the high-grade zones at the South West Oyu Tolgoi area (Kirwin et al. 2003, 2005a). The Kharmagtai area contains a Devonian siliciclastic sedimentary sequence that has been intruded by a number of monzodiorite and diorite porphyry stocks (Kirwin et al. 2005b). The inferred primary mineralogy of these intrusive rocks is consistent with a normal K-calc alkaline magmatic association. Arenaceous volcaniclastic units are composed of andesitic lava fragments and plagioclase and hornblende crystals. Felsic ash crystal tuffs, reworked tuffaceous sedimentary rocks, basaltic and andesitic volcanics have also been mapped at Zesen Uul. Numerous tourmaline breccia pipes are scattered throughout the district, the largest of which has a diameter of $500 \mathrm{~m}$ (Kirwin et al. 2005b).

The surface expression of copper mineralisation at Zesen Uul is sparse, comprising a few subcrops of microdiorite hosting rare quartz veins with traces of malachite and copper wad (Kirwin et al. 2005b). The near surface dimensions of the mineralised zone are approximately $200 \times 200 \mathrm{~m}$. A drill section through the central part of Zesen Uul is illustrated in Fig. 5b. The copper mineralisation occurs mainly as chalcopyrite with subordinate associated pyrite in and around stockwork quartz veins mostly hosted by monzodiorite. Mineralisation has been oxidized with development of a supergene zone extending to depths of $60 \mathrm{~m}$ below the surface.

The early A-type and associated veins hosting the sulphides are more planar than at Central Oyu Tolgoi, more typical of stockwork veins found in porphyry deposits elsewhere (e.g. Proffett 2003; Fig. 2b). The veins here display distinct sulphide zones commonly in the centre of the quartz veins. There is a close correlation between the density of quartz veins and the tenor of copper-gold mineralisation. Some later chalcopyrite-rich sulphide veins postdate the quartz stockwork event (Kirwin et al. 2005b). Magnetite occurs both in pre-sulphide quartz veins and within the sulphide-rich veins. The gold is found to be mainly hosted in chalcopyrite (Pollard and Taylor 2002) which commonly contains secondary micro-inclusions of silver tellurides, bismuthinite and native silver. Some tourmaline is associated with these copper-bearing quartz veins; however, most occurs associated with later pyrite-only

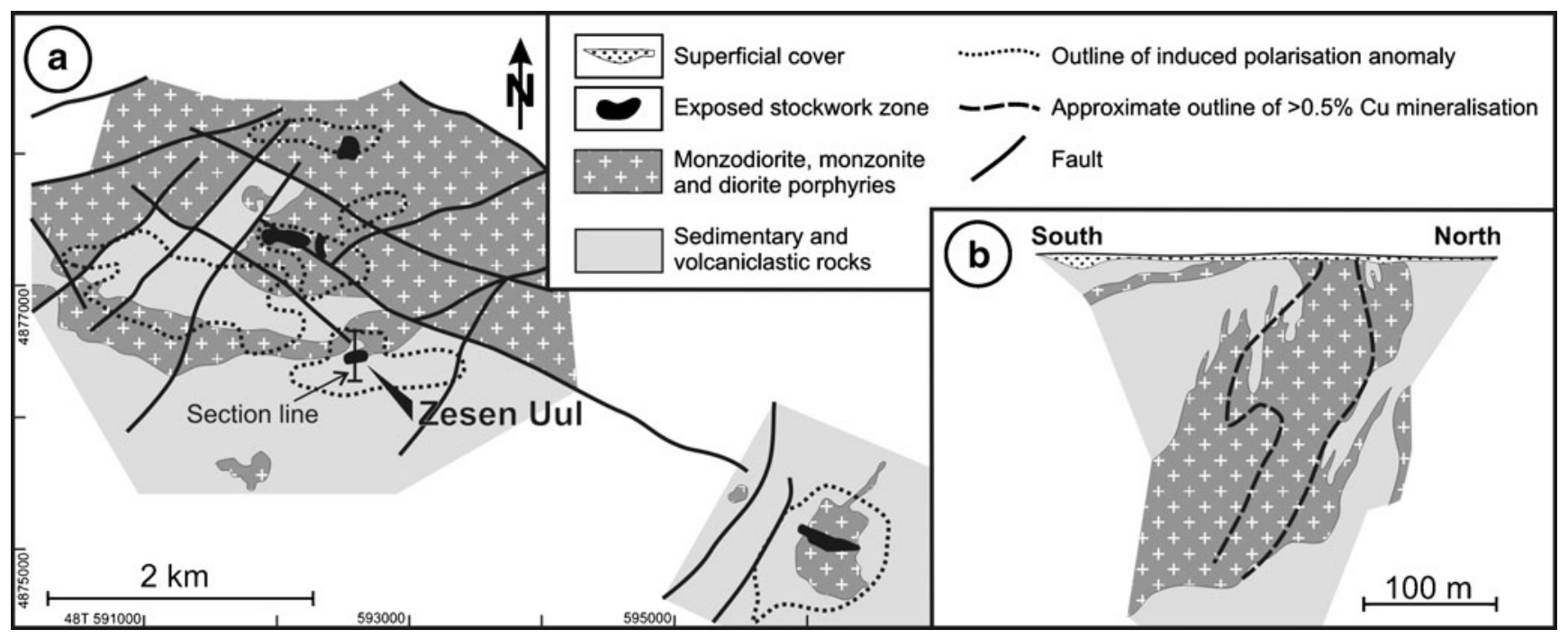

Fig. 5 a Simplified interpretative geological plan of the Kharmagtai district showing the main centres of porphyry-style Au-Cu mineralisation, including Zesen Uul. b Section through the Zesen Uul mineralised centre (modified after Kirwin et al. 2005b) 
veins. Narrow zones (normally $<10 \mathrm{~m}$ in width) of hydrothermal tourmaline breccias contain quartz-veined monzodiorite clasts in a matrix of quartz, tourmaline, sericite, pyrite and minor chalcopyrite. Other tourmaline breccias in the deposits are not accompanied by matrix sulphides (Kirwin et al. 2005a). Chalcopyrite and pyrite are overgrown by covellite, and the latter one is related to intense quartzcalcite veining.

Pervasive, selective potassic alteration of the rocks resulted in the limited textural destruction of the primary porphyritic texture leaving a mineral assemblage of quartzalbite-chlorite-magnetite-pyrite. However, in the most intensely potassic-altered zones, K-feldspar is common and the textural destruction is almost complete. Propylitic or phyllic alteration commonly overprints the precursor potassic assemblages.

The drill core samples examined from Zesen Uul were taken from the potassic-altered porphyry hosting the central quartz stockwork from a depth of between 20 and $110 \mathrm{~m}$. Alteration and mineralisation assemblages observed in the samples are illustrated in Fig. 6.

\section{Analytical methods}

Scanning electron microscope cathodoluminescence

Scanning electron microscope (SEM)-CL and BSE imaging was carried out using a JEOL 5900LV analytical SEM equipped with a GATAN MiniCL detector located at the Natural History Museum, London. The applied acceleration voltage and current were $20 \mathrm{kV}$ and $\sim 1 \mathrm{nA}$, respectively. The CL images were collected from four scans of $20 \mathrm{~s}$ photo speed each and a processing resolution of $1,280 \times 960$ pixels and 256 grey levels.

\begin{tabular}{|l|c|c|c|c|}
\hline \multicolumn{5}{|c|}{ Zesen Uul } \\
\hline \multicolumn{1}{|c|}{ mineral } & ZUi & $\begin{array}{c}\text { ZUii } \\
\text { main ore stage }\end{array}$ & ZUiii & $\begin{array}{c}\text { ZUiv quartz- } \\
\text { carbonate stage }\end{array}$ \\
\hline $\begin{array}{l}\text { ZUi quartz } \\
\text { ZUii quartz } \\
\text { ZUiii quartz } \\
\text { ZUiv quartz }\end{array}$ & & & & \\
\hline $\begin{array}{l}\text { magnetite } \\
\text { pyrite } \\
\text { actinolite } \\
\text { chalcopyrite } \\
\text { albite } \\
\text { chlorite } \\
\text { covellite } \\
\text { calcite } \\
\text { bismuthinite } \\
\text { tellurides } \\
\text { native Ag } \\
\text { epidote } \\
\text { native Au }\end{array}$ & & & & \\
\hline
\end{tabular}

Fig. 6 Mineral paragenesis and related quartz crystallisation sequence of the central stockwork at Zesen Uul observed in the studied samples
The different grey shades visualized in quartz crystals by SEM-CL reflect different luminescence colours. The variability in CL colour and intensity of quartz can be attributed to the presence of lattice defects (e.g. oxygen and silicon vacancies, broken bonds) and/or trace elements in the crystal structure (e.g. Götze et al. 2001). Some characteristic emission bands in the CL spectrum of quartz can be related to specific trace elements, e.g. $\mathrm{Al}^{3+}(3.64-3.76 \mathrm{eV}, 3.18 \mathrm{eV}$; ultraviolet to blue), $\mathrm{Ti}^{4+}\left(2.94-2.98 \mathrm{eV}\right.$; blue), $\mathrm{Fe}^{3+}$ (1.71$1.75 \mathrm{eV}$; red) and $\mathrm{H}^{+}(1.94-1.98 \mathrm{eV}$; red; Perny et al. 1992; Stevens-Kalceff and Phillips 1995; Demars et al. 1996; Müller et al. 2002). CL intensity in most high temperature quartz $\left(>500^{\circ} \mathrm{C}\right)$ has been shown to display a positive correlation with Ti concentration (Müller et al. 2000, 2002; Wark and Spear 2005); however, the physical mechanism of quartz luminescence is still not fully understood.

\section{Electron probe microanalysis}

Concentrations of $\mathrm{Al}, \mathrm{K}, \mathrm{Ti}$ and $\mathrm{Fe}$ in quartz were measured by EPMA using a JEOL $8900 \mathrm{RL}$ electron microprobe located at the Geowissenschaftliches Zentrum Göttingen, Germany. For high precision and sensitivity, an acceleration voltage of $20 \mathrm{kV}$, a beam current of $80 \mathrm{nA}$, a beam diameter of $5 \mu \mathrm{m}$ and counting times of $15 \mathrm{~s}$ for $\mathrm{Si}$ and of $300 \mathrm{~s}$ for $\mathrm{Al}, \mathrm{Ti}, \mathrm{K}$ and $\mathrm{Fe}$ were chosen. Limits of detection were $(3 \sigma$ of single point background) $13 \mu \mathrm{g} \mathrm{g}^{-1}$ for $\mathrm{Al}, 18 \mu \mathrm{g} \mathrm{g}^{-1}$ for $\mathrm{K}, 34 \mu \mathrm{g} \mathrm{g}^{-1}$ for Ti and $31 \mu \mathrm{g} \mathrm{g}^{-1}$ for Fe.

The Ti-in-quartz geothermometer of Wark and Watson (2006):

$$
T\left[{ }^{\circ} \mathrm{C}\right]=\frac{-3,765}{\log \left(\mathrm{Ti}\left[\mu \mathrm{g} \mathrm{g}^{-1}\right], \text { quartz } / a_{\mathrm{TiO}_{2}}\right)-5.69}-273
$$

provides a tool to determine the quartz crystallisation temperature based on the temperature dependence of the $\mathrm{Ti}^{4+}-\mathrm{Si}^{4+}$ substitution in quartz given the presence of rutile or, in its absence, an estimate of the $\mathrm{TiO}_{2}$ activity of the system. The geothermometer can be applied for temperatures in the range $400^{\circ} \mathrm{C}$ to $1,000^{\circ} \mathrm{C}$ at pressures of $1.0 \mathrm{GPa}$. Crystallisation temperatures of quartz with $\mathrm{Ti}>34 \mu \mathrm{g} \mathrm{g}^{-1}$ were then calculated using this formula.

\section{Fluid inclusion microthermometry}

The samples were prepared as doubly polished thick $(\sim 200 \mu \mathrm{m})$ sections for CL investigation, and these sections were afterward demounted and used as fluid inclusion wafers. Microthermometry was carried out using the joint IC/NHM facility comprising a Linkham THC600 heating/ freezing stage attached to an Olympus Optiphot microscope with a Nikon $\times 50$ long working distance lens. Calibration of the instrument was regularly monitored using standard 
artificial inclusion wafers. The fluid inclusion studies were carried out on the same samples as both the CL and microprobe analyses in order to directly relate the fluid inclusions to the individual quartz generations.

\section{Results}

Vein quartz textures visualized by SEM-CL

Using SEM-CL imagery on 60 samples originating from 12 drill cores (four drill cores from Central Oyu Tolgoi and eight drill cores from Zesen Uul), four major quartz generations were identified in the ore-bearing stockworks of the Central Oyu Tolgoi (OTi-OTiv) and Zesen Uul deposits (ZUi-ZUv). Figure 7 illustrates and summarizes the sequence of quartz crystallisation and the characteristic CL features of each quartz generation described below. The mineralisation stages related to the individual quartz generations are indicated in Figs. 4 and 6.

\section{Central Oyu Tolgoi}

The OTi stage is the oldest and most voluminous quartz generation and forms the primary network of A-type veins and is further evident as massive silicification of the host rock (Fig. 8a, b). In general, OTi quartz luminesces brightly under the SEM beam. OTi quartz occurs as subhedral comb-like crystals $(>200 \mu \mathrm{m})$ with oscillatory growth zoning developed in open cracks and vugs; smaller (5$200 \mu \mathrm{m})$ OTi crystals are also dispersed throughout the wall rock adjacent to the vein (Fig. 8a-c). Paragenetically, OTi predates the sulphide mineralisation and it is partially overgrown and replaced by the younger quartz generations OTii to OTiv, which have different zoning patterns and CL properties.

Widespread dissolution of OTi quartz occurred preferentially along crystal boundaries within A-type veins and along trans-granular, wormy micro-cracks which are healed by dull luminescent quartz of stage OTii (Fig. 8b, $\mathrm{d}-\mathrm{f}$ ). OTii quartz shows irregular, wavy CL structures and some domains of these structures have similar CL intensity to OTi, indicating that the OTii overprint is incomplete with some relics of OTi quartz preserved within OTii structures. It is therefore apparent that the major silica source for the precipitated OTii is likely to be from the dissolution of OTi quartz. The OTii quartz commonly contains fine-grained inclusions of both pyrite and chalcopyrite, which suggests that OTii accompanied the main sulphide mineralisation.

Both OTi and OTii quartz are penetrated by fine networks of thin, healed cracks (usually $<5 \mu \mathrm{m}$ wide) connecting domains $(<50 \mu \mathrm{m})$ of nearly non-luminescent
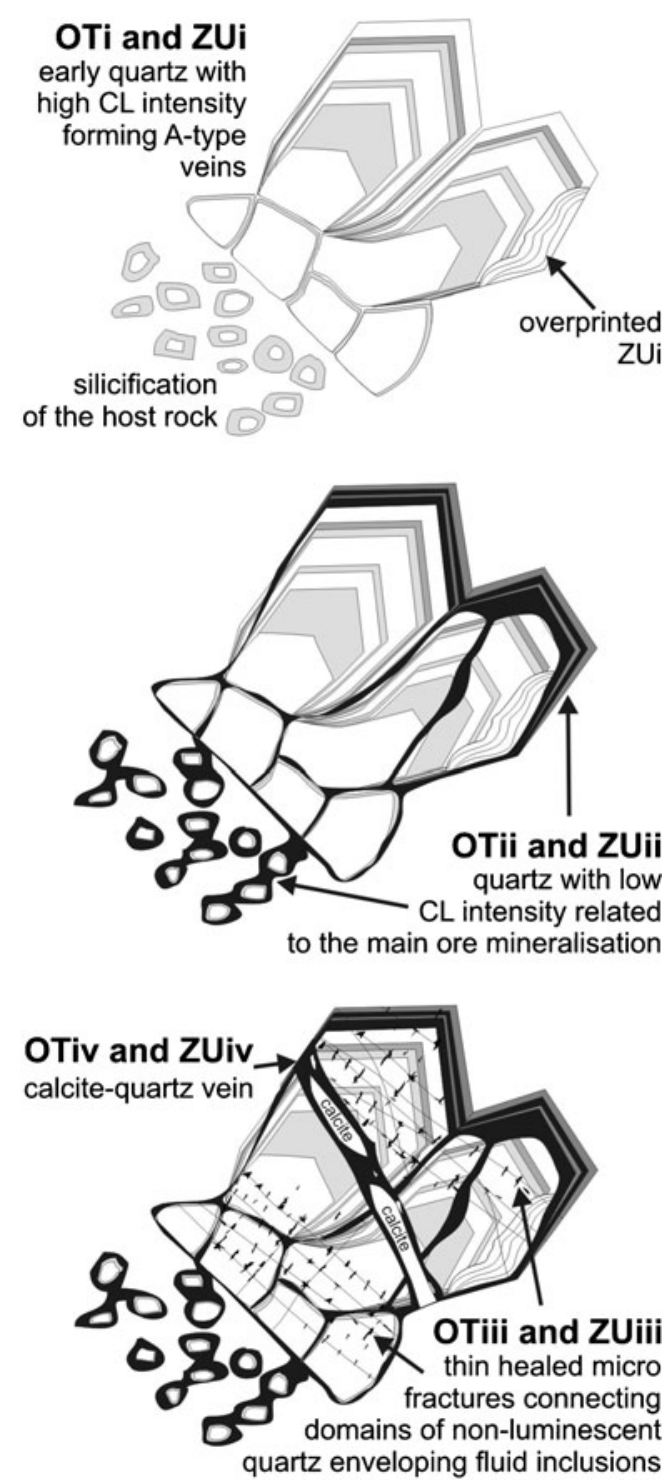

Fig. 7 Schematic diagram of the sequence of major quartz crystallisation stages in the central stockworks of the Central Oyu Tolgoi (OTi to OTiv) and Zesen Uul (ZUi to ZUiv) porphyry systems

quartz. These domains, which are interconnecting and commonly host fluid inclusions, represent another quartz generation, OTiii (Fig. 8c). Late micro-breccias crosscut quartz stages OTi to OTiii and these breccias are healed by another quartz generation OTiv, which is accompanied by calcite (Fig. 8f). These breccia veins are straight and are seen to crosscut all the previous quartz generations and structures.

\section{Zesen Uul}

In the Zesen Uul porphyry system, quartz of the ZUi stage forms mosaic-like crystal clusters in the host rock and comb-like arrays of quartz in early A-type and associated veins (Figs. $2 \mathrm{~b}$ and $9 \mathrm{a}-\mathrm{f}$ ). These vein structures appear 
Fig. 8 Growth and alteration textures of quartz from Central Oyu Tolgoi. a BSE image of the contact between the silicified host rock and A-type vein. Subhedral OTi quartz crystals nucleated at the wall rock contact. The vein is filled with pyrite $(p y)$, biotite $(b t)$ and pyrophyllite $(p r l)$. b SEM-CL image of the same area shown in a. OTi quartz shows bright CL. The weakly luminescent OTii quartz (black), which is related to the sulphide mineralisation, overgrew and replaced OTi quartz. c SEM-CL image of a OTi quartz crystal with concentric growth zoning. Thick weakly luminescent veins (black) are formed by OTii quartz. The dense network of thin healed fractures, which connect small non-luminescent (dull) domains, were deposited in stage OTiii. d SEM-CL image of mineralised A-type vein. Fe diffusion caused quenching of CL along the grain contact of quartz with pyrite $(p y)$, chalcopyrite (ccp) and biotite (bt; see also Fig. 10d). e BSE image of the same area shown in d. $\mathbf{f}$ SEM-CL image of central part of an A-type vein. The bright luminescent $\mathrm{OTi}$ quartz is replaced by dull luminescent OTii quartz along grain boundaries and irregular, crosscutting veins. These veins contain chalcopyrite $(c c p)$. A late planar OTiv quartz-calcite vein crosscuts OTi and OTii quartz
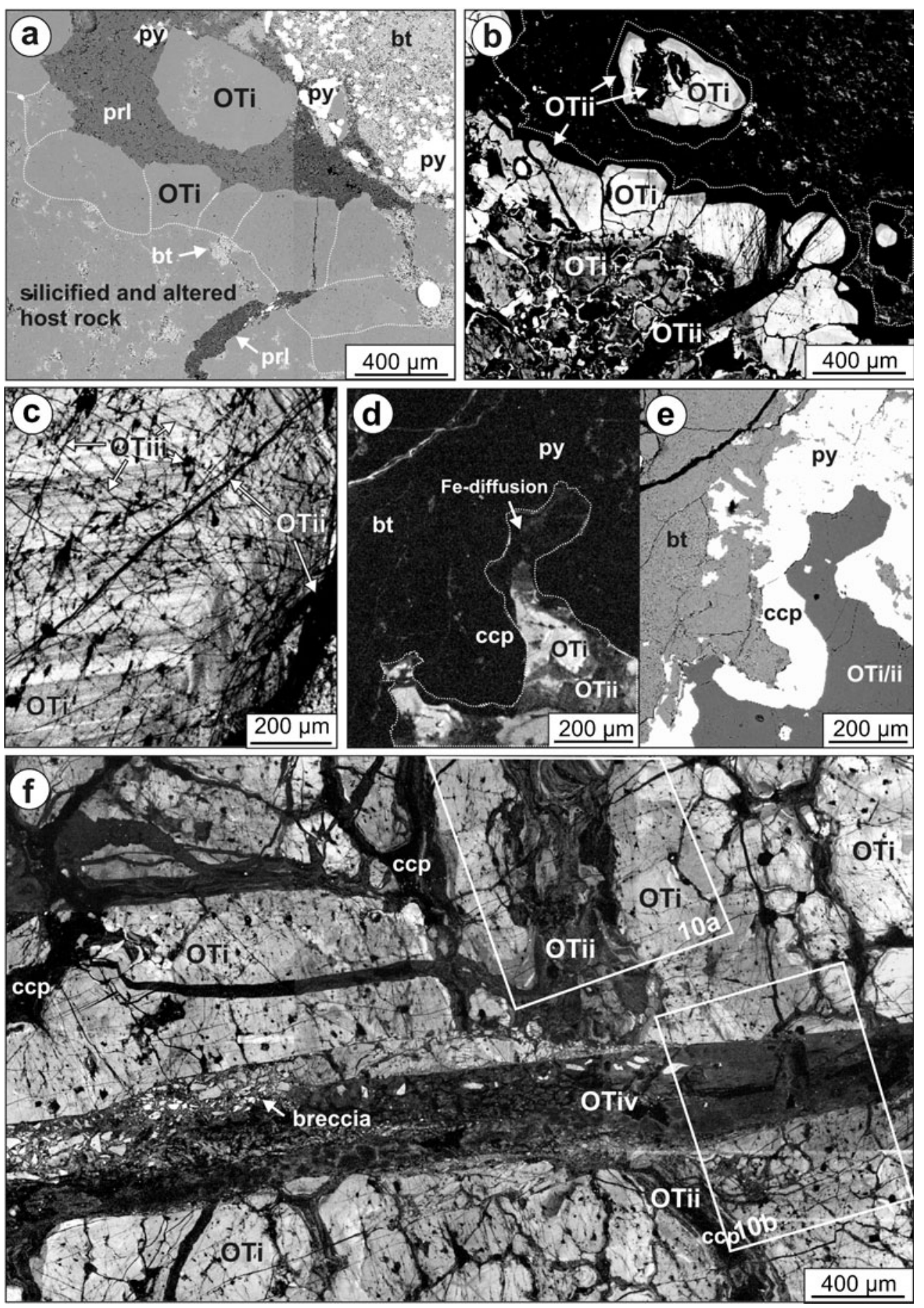

more aligned and regular compared to similar veins found in the central stockwork of the Central Oyu Tolgoi deposit. Most of the ZUi crystals show fine-scale oscillatory growth zoning with strong CL contrasts (Fig. 9b, c, e, f). The ZUi stage clearly predates the sulphide mineralisation. In this deposit, an overprint of ZUi quartz is seen occasionally, starting from grain boundaries; this has resulted in the homogenization of oscillatory growth zoning within ZUi (Fig. 9c, f). The overprinted domains are characterised by brightly luminescing and wavy zoned quartz with low CL contrasts (Fig. 9c). This type of overprint is observed in only a few samples, and the proportion of overprinted ZUi quartz is small, probably less than $1 \%$. The overprint did not result in the crystallisation of new quartz or associated minerals, and therefore, it is not considered as a separated crystallisation stage.

Dissolution of ZUi quartz preferentially along crystal boundaries was followed by the precipitation of ZUii quartz during the second major vein stage. Quartz of stage ZUii has very weak luminescence intensity and appears dark 
Fig. 9 Growth and alteration textures of quartz from Zesen Uul. a BSE image of an A-type vein with the typical mineral assemblage quartz ( $q t z)$, pyrite (py), chalcopyrite (ccp) and chlorite $(c h l)$. b CL image of the same area shown in a. c Detail of $\mathbf{b}$. Bright luminescent ZUi quartz with concentric growth zoning partially overprinted resulting in homogenisation of the zoning. $\mathbf{d} \mathrm{CL}$ image of comb quartz of an A-type vein. Bright luminescent and zoned $\mathrm{ZUi}$ quartz crystals nucleated on the wall rock. These crystals were subsequently dissolved and overgrown by weakly luminescent, zoned ZUii quartz. e Detail of the CL image $\mathbf{d}$ (rotated) showing the oscillatory zoned ZUi quartz and its marginal resorption (arrows). f Concentric zoned ZUi quartz overprinted and overgrown by ZUii quartz (black). g Weak luminescent ZUii quartz with oscillatory and sector zoning. Fe diffusion caused the CL quenching at the crystal margins
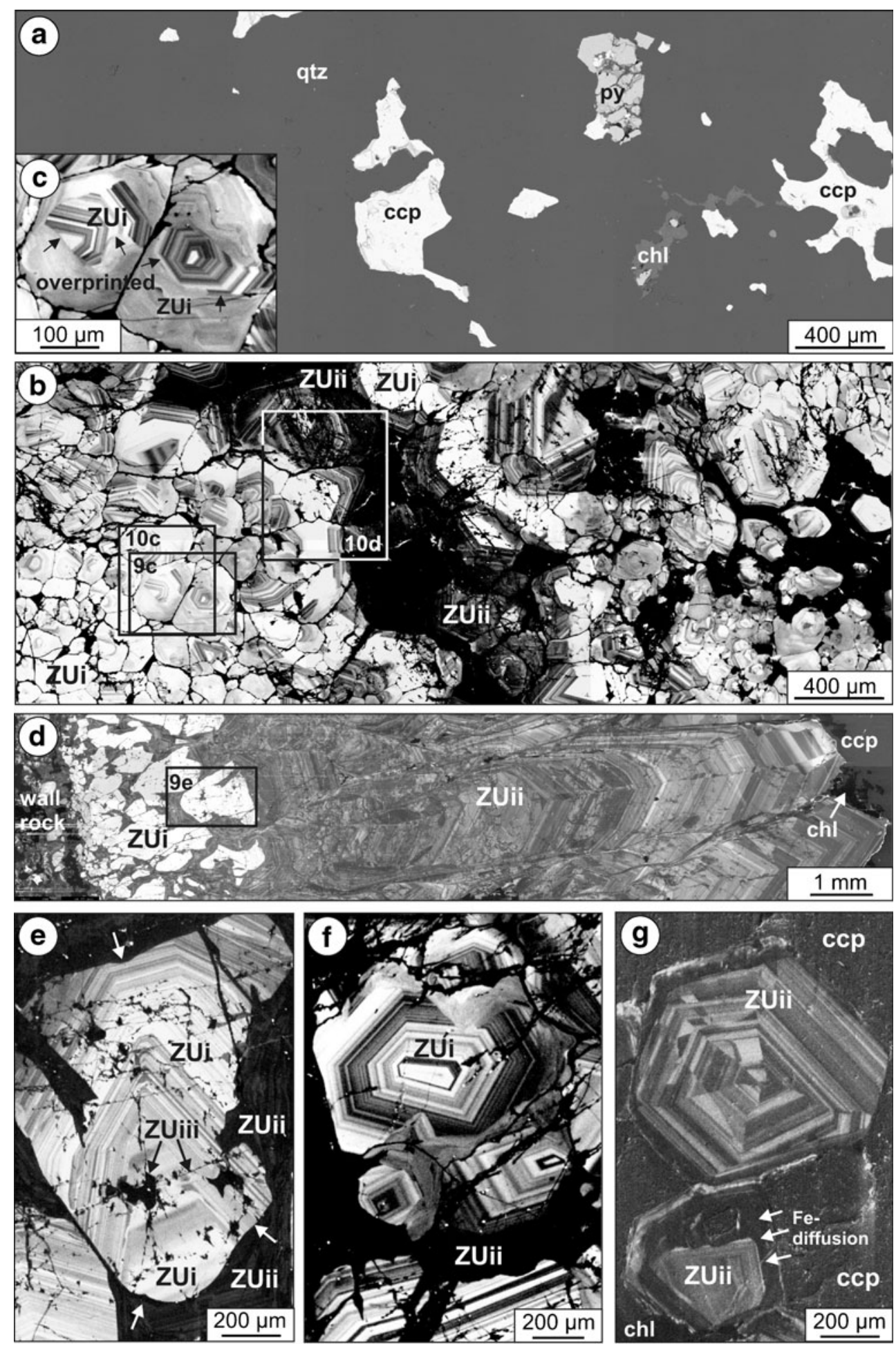

grey and black in the printed SEM-CL images (Fig. 9b, d, e, g). Comb-like ZUii crystals with oscillatory zoning are seen overgrowing ZUi crystals where open space growth permitted (Fig. 9d). This zoning becomes visible only in $\mathrm{CL}$ if both high beam current and image contrast are applied. Crystallisation of ZUii quartz is synchronous with the main pyrite-chalcopyrite mineralisation. Generally, the
CL features of quartz ZUii are similar to that of the OTii from Central Oyu Tolgoi; however, comb-like crystals with planar growth zones are more common in the ZUii stage, and some of these crystals show sector zoning, which is typical of hydrothermal quartz (Fig. 9g).

The quartz of the ZUiii stage shows similar structures to the OTiii stage at the Central Oyu Tolgoi deposit, but the 
event was not as intensely developed at Zesen Uul (Fig. 9e). Generations ZUi to ZUiii are crosscut by planar ZUiv quartz-calcite veins. In contrast to the OTiv-calcite veins of Central Oyu Tolgoi, the Zesen Uul ZUiv-calcite veins contain a much smaller proportion of quartz and calcite is the dominant mineral in the veins. Occasionally, euhedral amethyst crystals up to $1 \mathrm{~cm}$ in size are developed in the ZUiv veins, and in other places, ZUiv vein quartz contains inclusions of covellite.

\section{Trace elements of quartz}

Central Oyu Tolgoi

$\mathrm{Al}, \mathrm{K}$, Ti and Fe were measured using EPMA along traverses transecting the different quartz generations (Fig. 10). Concentrations of these elements vary considerably among the different generations (Table 1), yet contacts between the different quartz generations are characterised by sharp concentration steps in all four of the elements measured (Fig. 10). Differences in the trace element signature among the quartz generations are illustrated by the variation diagrams shown in Figs. 11 and 12.

The unmineralised quartz generations OTi and OTiii have relatively low and consistent $\mathrm{Al}$ concentrations with averages of 263 and $112 \mu \mathrm{g} \mathrm{g}^{-1}$, respectively (Fig. 11). In contrast, OTii and OTiv have high and very variable $\mathrm{Al}$ contents (Fig. 10a, b). Concentrations of K are consistently low for OTi, OTiii and OTiv but high for OTii with a wide range of values (Figs. 11 and 12). OTi quartz has the highest average Ti of $69 \mu \mathrm{g} \mathrm{g}^{-1}$ (Fig. 12). The Fe content is relatively consistent for most quartz generations, lying in the range 30 to $150 \mu \mathrm{g} \mathrm{g}^{-1}$. A few analyses of OTi and OTiv show higher Fe concentrations of up to $567 \mu \mathrm{g} \mathrm{g}^{-1}$. These elevated $\mathrm{Fe}$ concentrations were detected close to the contact between OTi quartz and OTiv quartz-calcite veins (Fig. 10b).
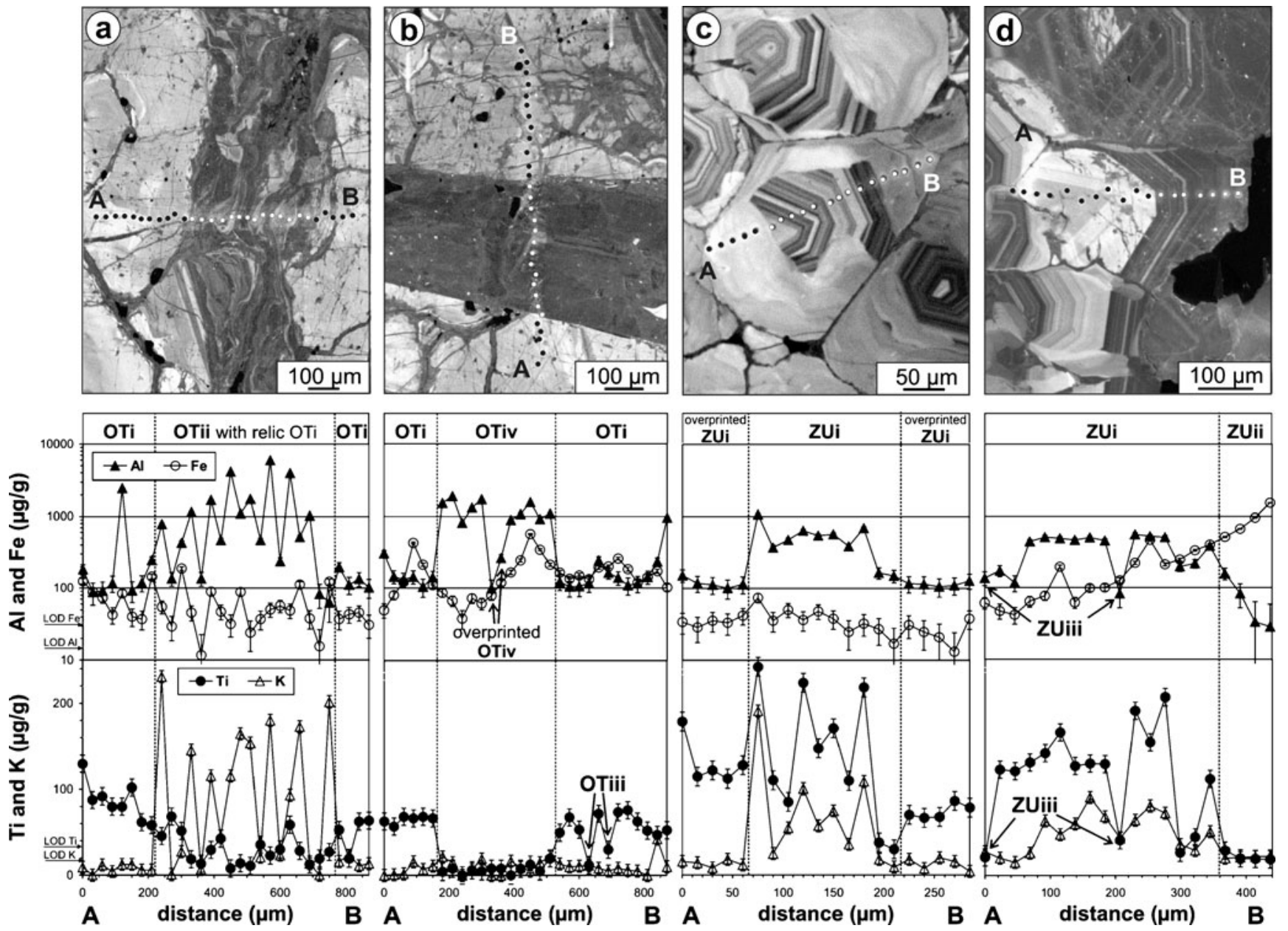

Fig. 10 Trace element profiles across different quartz generations from Central Oyu Tolgoi $(\mathbf{a}, \mathbf{b})$ and Zesen Uul $(\mathbf{c}, \mathbf{d})$. Small dots in the SEM-CL images indicate locations of the microprobe analyses. The

related profiles are plotted below the images. Positions of the profiles are shown in Figs. $8 \mathrm{f}$ and $9 \mathrm{~b}$ at a larger scale 
Table 1 Trace element concentrations of quartz generations of the Central Oyu Tolgoi (COT samples) and Zesen Uul (ZU samples) porphyry deposits determined by EPMA

\begin{tabular}{|c|c|c|c|c|c|c|}
\hline Sample & $\begin{array}{l}\text { qtz } \\
\text { gener. }\end{array}$ & $\begin{array}{l}\text { dist. } \\
(\mu \mathrm{m})\end{array}$ & $\begin{array}{l}\mathrm{Al} \\
\left(\mu \mathrm{gg}^{-1}\right)\end{array}$ & $\begin{array}{l}\mathrm{K} \\
\left(\mu \mathrm{gg}^{-1}\right)\end{array}$ & $\begin{array}{l}\mathrm{Ti} \\
\left(\mu g g^{-1}\right)\end{array}$ & $\begin{array}{l}\mathrm{Fe} \\
\left(\mu g g^{-1}\right)\end{array}$ \\
\hline \multirow{30}{*}{$\begin{array}{c}\text { COT226- } \\
573\end{array}$} & OTi & 0 & 182 & $<18$ & 129 & 125 \\
\hline & OTi & 30 & 88 & $<18$ & 88 & 89 \\
\hline & OTi & 60 & 92 & $<18$ & 92 & 73 \\
\hline & OTi & 90 & 117 & $<18$ & 80 & 43 \\
\hline & OTi & 120 & 2,483 & $<18$ & 80 & 84 \\
\hline & OTi & 150 & 93 & $<18$ & 102 & 40 \\
\hline & OTi & 180 & 119 & $<18$ & 62 & 37 \\
\hline & OTi & 210 & 245 & $<18$ & 58 & 144 \\
\hline & OTii & 240 & 785 & 231 & 46 & 55 \\
\hline & OTi* & 270 & 136 & $<18$ & 68 & $<31$ \\
\hline & OTi* & 300 & 430 & 27 & 52 & 188 \\
\hline & OTii & 330 & 1,151 & 145 & $<34$ & 46 \\
\hline & OTi* & 360 & 136 & $<18$ & $<34$ & $<31$ \\
\hline & OTii & 390 & 1,698 & 115 & $<34$ & 89 \\
\hline & OTi* & 420 & 468 & 46 & 42 & 47 \\
\hline & OTii & 450 & 4,133 & 115 & $<34$ & 32 \\
\hline & OTii & 480 & 1,094 & 164 & $<34$ & 89 \\
\hline & OTii & 510 & 1,749 & 154 & $<34$ & $<31$ \\
\hline & OTi* & 540 & 468 & 21 & 35 & 37 \\
\hline & OTii & 570 & 5,948 & 180 & $<34$ & 50 \\
\hline & OTi* & 600 & 236 & 23 & $<34$ & 57 \\
\hline & OTii & 630 & 3,959 & 93 & 59 & 49 \\
\hline & OTii & 660 & 517 & 173 & $<34$ & 112 \\
\hline & OTii & 690 & 1,026 & $<18$ & $<34$ & 38 \\
\hline & OTi* & 720 & 83 & $<18$ & $<34$ & $<31$ \\
\hline & OTii & 750 & 64 & 202 & $<34$ & 123 \\
\hline & OTi & 780 & 197 & $<18$ & 53 & 37 \\
\hline & OTi* & 810 & 111 & 23 & $<34$ & 43 \\
\hline & OTi & 840 & 135 & $<18$ & 62 & 46 \\
\hline & OTi & 870 & 102 & $<18$ & 64 & 31 \\
\hline \multirow{16}{*}{$\begin{array}{l}\text { COT226- } \\
573\end{array}$} & OTi & 0 & 304 & $<18$ & 63 & 50 \\
\hline & OTi & 30 & 145 & $<18$ & 56 & 80 \\
\hline & OTi & 60 & 131 & $<18$ & 68 & 121 \\
\hline & OTi & 90 & 144 & $<18$ & 66 & 428 \\
\hline & OTi & 120 & 104 & $<18$ & 68 & 213 \\
\hline & OTi & 150 & 142 & $<18$ & 66 & 110 \\
\hline & OTiv & 180 & 1,528 & 21 & $<34$ & 86 \\
\hline & OTiv & 210 & 1,901 & $<18$ & $<34$ & 67 \\
\hline & OTiv & 240 & 812 & $<18$ & $<34$ & 38 \\
\hline & OTiv & 270 & 1,320 & $<18$ & $<34$ & 72 \\
\hline & OTiv & 300 & 1,729 & 19 & $<34$ & 61 \\
\hline & OTiv* & 330 & 100 & $<18$ & $<34$ & 78 \\
\hline & OTiv* & 360 & 264 & $<18$ & $<34$ & 119 \\
\hline & OTiv & 390 & 891 & $<18$ & $<34$ & 166 \\
\hline & OTiv & 420 & 1,076 & $<18$ & $<34$ & 245 \\
\hline & OTiv & 450 & 1,578 & $<18$ & $<34$ & 567 \\
\hline
\end{tabular}

Table 1 (continued) \begin{tabular}{lllllll}
\hline Sample & qtz & $\begin{array}{l}\text { dist. } \\
\text { gener. }\end{array}$ & $\begin{array}{l}\mathrm{Al} \\
(\mu \mathrm{m})\end{array}$ & $\begin{array}{l}\mathrm{K} \\
\left(\mu g^{-1}\right)\end{array}$ & $\begin{array}{l}\mathrm{Ti} \\
\left(\mu g^{-1}\right)\end{array}$ & $\begin{array}{l}\mathrm{Fe} \\
\left(\mu \mathrm{gg}^{-1}\right)\end{array}$ \\
$\left(\mu g^{-1}\right)$
\end{tabular}

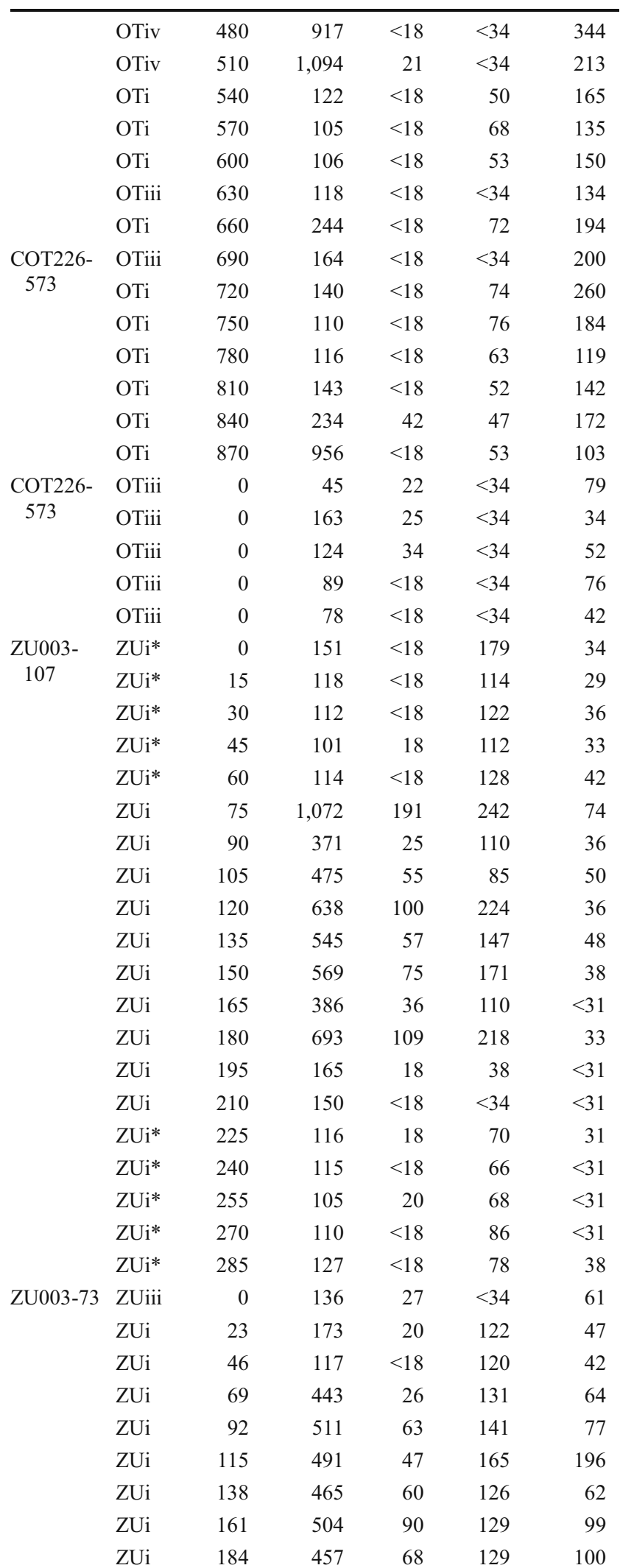


Table 1 (continued)

\begin{tabular}{lllllll}
\hline Sample & qtz & dist. & $\mathrm{Al}$ & $\mathrm{K}$ & $\mathrm{Ti}$ & $\mathrm{Fe}$ \\
gener. & $(\mu \mathrm{m})$ & $\left(\mu g g^{-1}\right)$ & $\left(\mu g g^{-1}\right)$ & $\left(\mu g g^{-1}\right)$ & $\left(\mu g g^{-1}\right)$
\end{tabular}

\begin{tabular}{|c|c|c|c|c|c|c|}
\hline & ZUiii & 207 & 83 & 43 & 41 & 127 \\
\hline & $\mathrm{ZUi}$ & 230 & 557 & 64 & 191 & 222 \\
\hline & ZUi & 253 & 526 & 80 & 154 & 468 \\
\hline & ZUi & 276 & 508 & 72 & 206 & 212 \\
\hline & ZUi & 299 & 198 & 36 & $<34$ & 247 \\
\hline & ZUi & 322 & 218 & 29 & 44 & 334 \\
\hline & ZUi & 345 & 385 & 51 & 112 & 400 \\
\hline & ZUi & 368 & 158 & 20 & $<34$ & 514 \\
\hline & ZUi & 391 & 83 & 21 & $<34$ & 667 \\
\hline & ZUi & 414 & 33 & 21 & $<34$ & 952 \\
\hline & ZUi & 437 & 28 & 22 & $<34$ & 1,541 \\
\hline ZU025-17 & ZUii & 0 & 239 & 7 & 0 & 6 \\
\hline \multirow[t]{11}{*}{ ZU025-17 } & ZUii & 15 & 39 & $<18$ & $<34$ & $<31$ \\
\hline & ZUii & 30 & 49 & $<18$ & $<34$ & $<31$ \\
\hline & ZUii & 45 & 70 & $<18$ & $<34$ & $<31$ \\
\hline & ZUii & 60 & 70 & $<18$ & $<34$ & $<31$ \\
\hline & ZUii & 75 & 147 & $<18$ & $<34$ & $<31$ \\
\hline & ZUii & 90 & 126 & $<18$ & $<34$ & $<31$ \\
\hline & ZUii & 105 & 178 & $<18$ & $<34$ & $<31$ \\
\hline & ZUii & 120 & 189 & $<18$ & $<34$ & $<31$ \\
\hline & ZUii & 135 & 312 & $<18$ & $<34$ & $<31$ \\
\hline & ZUii & 150 & 1,030 & 22 & $<34$ & 40 \\
\hline & ZUii & 165 & 2,113 & 42 & $<34$ & $<31$ \\
\hline \multirow[t]{25}{*}{ ZU025-17 } & ZUii & 0 & 67 & $<18$ & $<34$ & 1,574 \\
\hline & ZUii & 20 & 29 & $<18$ & $<34$ & 757 \\
\hline & ZUii & 40 & 96 & $<18$ & $<34$ & 502 \\
\hline & ZUii & 60 & 1,731 & $<18$ & $<34$ & 359 \\
\hline & ZUii & 80 & 152 & $<18$ & $<34$ & 241 \\
\hline & ZUii & 100 & 218 & $<18$ & $<34$ & 187 \\
\hline & ZUii & 120 & 59 & $<18$ & $<34$ & 152 \\
\hline & ZUii & 140 & 44 & $<18$ & $<34$ & 108 \\
\hline & ZUii & 160 & 105 & $<18$ & $<34$ & 94 \\
\hline & ZUii & 180 & 392 & $<18$ & $<34$ & 96 \\
\hline & ZUii & 200 & 661 & $<18$ & $<34$ & 86 \\
\hline & ZUii & 220 & 447 & $<18$ & $<34$ & 62 \\
\hline & ZUii & 240 & 140 & $<18$ & $<34$ & 65 \\
\hline & ZUii & 260 & 210 & $<18$ & $<34$ & 61 \\
\hline & ZUii & 280 & 4,260 & $<18$ & $<34$ & 98 \\
\hline & ZUii & 300 & 178 & $<18$ & $<34$ & 40 \\
\hline & ZUii & 320 & 106 & $<18$ & $<34$ & 53 \\
\hline & ZUii & 340 & 500 & $<18$ & $<34$ & 40 \\
\hline & ZUii & 360 & 8,659 & $<18$ & $<34$ & 89 \\
\hline & ZUii & 380 & 7,630 & $<18$ & $<34$ & 132 \\
\hline & ZUii & 400 & 336 & $<18$ & $<34$ & 81 \\
\hline & ZUii & 420 & 182 & $<18$ & $<34$ & 61 \\
\hline & ZUii & 440 & 1,713 & $<18$ & $<34$ & 57 \\
\hline & ZUii & 460 & 885 & $<18$ & $<34$ & 50 \\
\hline & ZUii & 480 & 1,092 & $<18$ & $<34$ & 48 \\
\hline
\end{tabular}

Table 1 (continued)

Sample qtz dist. Al $\quad \mathrm{K} \quad \mathrm{Ti} \quad \mathrm{Fe}$ $\begin{array}{lllll}\text { gener. } \quad(\mu \mathrm{m}) \quad\left(\mu g g^{-1}\right) & \left(\mu g g^{-1}\right) & \left(\mu g g^{-1}\right) & \left(\mu g g^{-1}\right)\end{array}$

\begin{tabular}{|c|c|c|c|c|c|c|}
\hline & ZUii & 500 & 142 & $<18$ & $<34$ & 47 \\
\hline & ZUii & 520 & 181 & $<18$ & $<34$ & 50 \\
\hline & ZUii & 540 & 865 & $<18$ & $<34$ & 63 \\
\hline & ZUii & 560 & 511 & $<18$ & $<34$ & 80 \\
\hline & ZUii & 580 & 1,263 & $<18$ & $<34$ & 67 \\
\hline & ZUii & 600 & 2,720 & $<18$ & $<34$ & 105 \\
\hline & ZUii & 620 & 2,676 & $<18$ & $<34$ & 91 \\
\hline & ZUii & 640 & 1,607 & $<18$ & $<34$ & 105 \\
\hline & ZUii & 660 & 1,194 & $<18$ & $<34$ & 135 \\
\hline & ZUii & 680 & 116 & $<18$ & $<34$ & 188 \\
\hline \multirow[t]{4}{*}{ ZU025-17 } & ZUii & 700 & 91 & $<18$ & $<34$ & 251 \\
\hline & ZUii & 720 & 102 & $<18$ & $<34$ & 357 \\
\hline & ZUii & 740 & 83 & $<18$ & $<34$ & 553 \\
\hline & ZUii & 760 & 95 & $<18$ & $<34$ & 986 \\
\hline \multirow[t]{30}{*}{ ZU003-72 } & ZUii & 0 & 270 & $<18$ & $<34$ & 229 \\
\hline & ZUii & 20 & 1,468 & 32 & $<34$ & 225 \\
\hline & ZUii & 40 & 346 & 42 & 34 & 196 \\
\hline & ZUii & 60 & 523 & 37 & $<34$ & 162 \\
\hline & ZUii & 80 & 195 & $<18$ & $<34$ & 162 \\
\hline & ZUii & 100 & 893 & $<18$ & $<34$ & 155 \\
\hline & ZUii & 120 & 366 & 50 & $<34$ & 161 \\
\hline & ZUii & 140 & 181 & $<18$ & $<34$ & 123 \\
\hline & ZUii & 160 & 1,731 & 46 & $<34$ & 184 \\
\hline & ZUii & 180 & 610 & 24 & $<34$ & 176 \\
\hline & ZUii & 200 & 645 & 60 & $<34$ & 243 \\
\hline & ZUiv & 220 & 2,027 & 25 & $<34$ & 208 \\
\hline & ZUiv & 240 & 3,752 & 32 & $<34$ & 242 \\
\hline & ZUiv & 260 & 2,595 & $<18$ & $<34$ & 285 \\
\hline & ZUiv & 280 & 2,073 & 38 & $<34$ & 291 \\
\hline & ZUiv & 300 & 2,335 & 56 & $<34$ & 315 \\
\hline & ZUiv & 320 & 2,308 & 23 & $<34$ & 332 \\
\hline & ZUiv & 340 & 2,240 & 18 & $<34$ & 372 \\
\hline & ZUiv & 360 & 1,817 & $<18$ & $<34$ & 404 \\
\hline & ZUiv & 380 & 1,332 & $<18$ & $<34$ & 453 \\
\hline & ZUiv & 400 & 1,711 & 22 & $<34$ & 523 \\
\hline & ZUiv & 420 & 2,188 & 18 & $<34$ & 650 \\
\hline & ZUiv & 440 & 2,849 & 204 & $<34$ & 852 \\
\hline & ZUiv & 460 & 2,247 & 59 & $<34$ & 1,483 \\
\hline & ZUiv & 480 & 2,202 & 61 & $<34$ & 1,356 \\
\hline & ZUii & 500 & 573 & 47 & $<34$ & 839 \\
\hline & ZUii & 520 & 541 & 48 & $<34$ & 778 \\
\hline & ZUii & 540 & 349 & 20 & $<34$ & 793 \\
\hline & ZUii & 560 & 743 & $<18$ & $<34$ & 1,069 \\
\hline & ZUii & 580 & 618 & 21 & $<34$ & 1,503 \\
\hline \multirow{4}{*}{$\begin{array}{l}\text { ZU005- } \\
288\end{array}$} & ZUiv & 0 & 4,435 & 92 & $<34$ & 49 \\
\hline & ZUiv & 20 & 4,976 & 157 & $<34$ & 31 \\
\hline & ZUiv & 40 & 4,033 & 113 & $<34$ & $<31$ \\
\hline & ZUiv & 60 & 3,435 & 122 & $<34$ & $<31$ \\
\hline
\end{tabular}


Table 1 (continued)

\begin{tabular}{llrrrrr}
\hline Sample & $\begin{array}{l}\text { qtz } \\
\text { gener. }\end{array}$ & $\begin{array}{l}\text { dist. } \\
(\mu \mathrm{m})\end{array}$ & $\begin{array}{l}\mathrm{Al} \\
\left(\mu \mathrm{gg}^{-1}\right)\end{array}$ & $\begin{array}{l}\mathrm{K} \\
\left(\mu \mathrm{gg}^{-1}\right)\end{array}$ & $\begin{array}{l}\mathrm{Ti} \\
\left(\mu \mathrm{gg}^{-1}\right)\end{array}$ & $\begin{array}{l}\mathrm{Fe} \\
\left(\mu \mathrm{gg}^{-1}\right)\end{array}$ \\
\hline ZUiv & 80 & 2,858 & 86 & $<34$ & 42 \\
ZUiv & 100 & 2,913 & 71 & $<34$ & 35 \\
ZUiv & 120 & 3,792 & 214 & $<34$ & 32 \\
ZUiv & 140 & 3,771 & 24 & $<34$ & $<31$ \\
ZUiv & 160 & 4,030 & 19 & $<34$ & $<31$ \\
ZUiv & 180 & 4,145 & 29 & $<34$ & $<31$ \\
ZUiv & 200 & 4,448 & 206 & $<34$ & $<31$ \\
ZUiv & 220 & 4,101 & 117 & $<34$ & 34
\end{tabular}

The concentrations were predominantly analyzed along traverses with distances of 15 to $30 \mu \mathrm{m}$ between the analysis spots

dist. distance, qtz gener. quartz generation, OTi* relic OTi in OTii structures, OTiv ${ }^{*}$ overprinted OTiv, $Z_{U i}{ }^{*}$ overprinted (homogenized) ZUi

\section{Zesen Uul}

The ZUii and ZUiv quartz from the Zesen Uul veins are similar to OTii and OTiv quartz from the Central Oyu Tolgoi veins with high average $\mathrm{Al}$ contents of 795 and $3,024 \mu \mathrm{g} \mathrm{g}^{-1}$, respectively, showing a widespread (Fig. 11). The Al contents of ZUi and ZUiii quartz are significantly lower. ZUi and ZUiv are characterised by high and variable concentrations of $\mathrm{K}$, leading to different distribution patterns of $\mathrm{K}$ compared with the corresponding generations of quartz OTi and OTiv at Central Oyu Tolgoi (Fig. 11). Concentrations of $\mathrm{Ti}$ in $\mathrm{ZUi}$ quartz are very high and variable (Fig. 12); this is the quartz generation with the highest average $\mathrm{Ti}$ content of $133 \mu \mathrm{g} \mathrm{g}^{-1}$. The average $\mathrm{Ti}$ content in ZUii, ZUiii and ZUiv quartz is below the limit of detection $\left(<34 \mu \mathrm{g} \mathrm{g}^{-1}\right)$.

The overprinted ZUi shows slightly lower and more consistent concentrations of $\mathrm{Ti}, \mathrm{Al}$ and $\mathrm{K}$ compared to $\mathrm{ZUi}$ indicating that the overprint has resulted in homogenization of the element distribution (Fig. 10c). Some narrow, weakly luminescent outer growth zones of ZUi (Fig. 10d) show both low $\mathrm{Ti}\left(\leq 44 \mu \mathrm{g} \mathrm{g}^{-1}\right)$ and $\mathrm{Al}\left(136\right.$ to $\left.218 \mu \mathrm{g} \mathrm{g}^{-1}\right)$ values. These zones are preferentially developed at the margin of ZUi quartz crystals where they pass into ZUii quartz. In general, high Ti correlates with growth zones of very bright $\mathrm{CL}$, whereas the total $\mathrm{Al}$ content shows no uniform correlation with CL intensity.

ZUii and ZUiv quartz containing high Al also show high concentrations of $\mathrm{Fe}$, albeit with a widespread in the data (Fig. 11). The profile in Fig. 10d illustrates that the highest Fe concentrations occur in quartz close to the contact with Fe-rich sulphide phases. In this case, the highest $\mathrm{Fe}$ concentrations are likely to be caused by diffusion of Fe from the sulphide into the quartz as discussed by Penniston-
Dorland (2001). Analyses performed far away (>500 $\mu \mathrm{m})$ from Fe-rich minerals do not show this effect.

\section{Fluid inclusion microthermometry}

Petrography and microthermometry were completed on 80 fluid inclusions from the same samples that were examined using CL and EPMA. However, only 29 fluid inclusions could be related with certainty to the specific quartz generations analyzed. As mentioned above, fluid inclusions that can be utilised for thermometric studies are rare and very small in both deposits compared to other porphyry systems. Therefore, the few data collected are used here only to estimate the approximate crystallisation temperatures of the individual quartz generations (Table 2). Due to the limited number of fluid inclusion analyses possible, the temperature ranges and salinities listed in Table 2 may not be truly representative of the variability of the systems.

The paragenetic sequences of fluid inclusions hosted in the different quartz generations from Central Oyu Tolgoi and Zesen Uul deposits are generally similar. OTi and ZUi quartz contain glassy, partially crystallised silicate melt inclusions, commonly with small daughter minerals such as biotite and feldspar-like phases, together with a vapour phase/shrinkage bubble. These inclusions start to melt at $675^{\circ} \mathrm{C}$ at $1 \mathrm{~atm}$ external pressure. Primary fluid inclusions related to the overprinted ZUi quartz of Zesen Uul could not be identified.

The OTii and ZUii quartz is seen to encapsulate chalcopyrite and pyrite grains in the same regions where it hosts two types of primary fluid inclusions. These two inclusion types are (1) liquid-rich inclusions that have high and very variable salinities, some with daughter phases, together with (2) vapour-rich inclusions. It is tentatively suggested that the solid-bearing and vapour-rich inclusions could be coexisting pairs trapped in a boiling fluid. Halite daughter crystals in the liquid-rich inclusions indicate very high salinities for many primary fluid inclusions in OTii and ZUii quartz. Most of the liquid-rich inclusions contain, in addition to halite, other solid, partially opaque phases that are suspected to be sulphides (Fig. 13). These inclusions record homogenization temperatures of $265^{\circ} \mathrm{C}$ to $305^{\circ} \mathrm{C}$ in the Central Oyu Tolgoi samples and $315^{\circ} \mathrm{C}$ to $417^{\circ} \mathrm{C}$ in the Zesen Uul samples. The corresponding trapping temperatures are $296^{\circ} \mathrm{C}$ to $340^{\circ} \mathrm{C}$ and $353^{\circ} \mathrm{C}$ to $445^{\circ} \mathrm{C}$, respectively, after applying a temperature correction using the method of Brown and Lamb (1989). A pressure correction of 0.5 kbar was applied which corresponds approximately to the assumed pressure of stockwork formation of both deposits (Perelló et al. 2001). The applied pressure correction is a simplified approximation because fluctuations between lithostatic and hydrostatic 
Fig. 11 Variations in concentrations of $\mathrm{Al}, \mathrm{K}$, Ti and $\mathrm{Fe}$ between the different quartz generations. The average concentrations shown as black bars are connected by a solid line. The hatched areas highlight the concentrations in OTii, OTiv, ZUii and ZUiv quartz that are associated with sulphide mineralisation. In cases where the average concentration is below the limit of detection ( $L O D)$ the concentration has been equated with the LOD. Concentrations of relic OTi quartz in OTii structures and of overprinted OTiv and ZUi quartz are not considered (see Table 1)

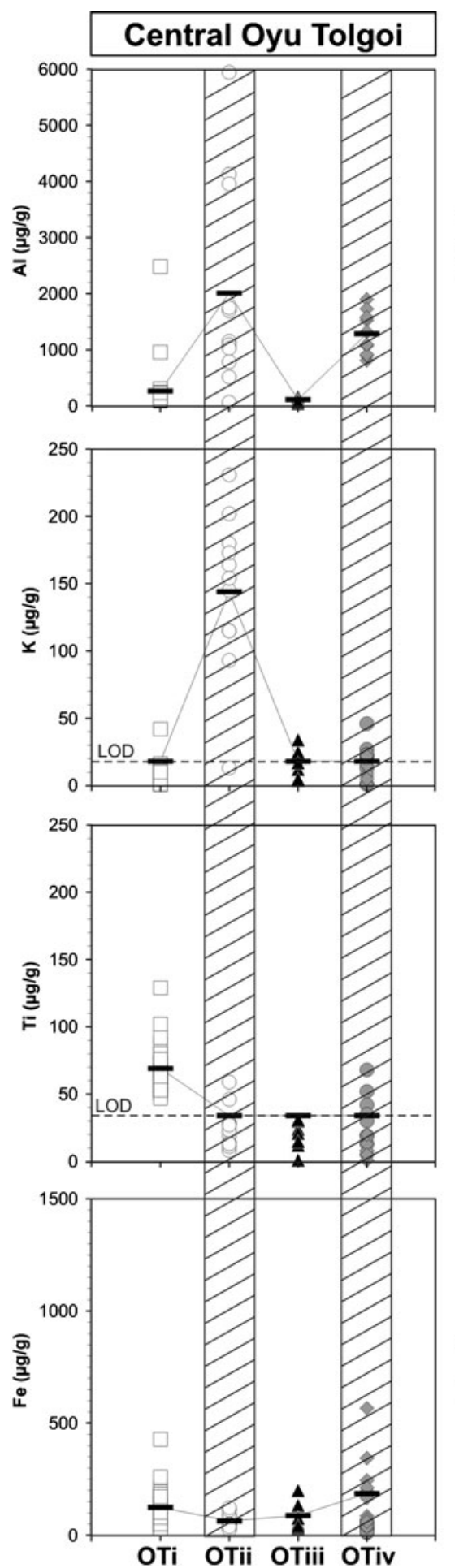

pressure are likely to have occurred as a result of rupture and self-sealing of the porphyry system. This may have caused pressure variations in the range of 0.5 to $1 \mathrm{kbar}$ (see discussion). However, the observed inclusion assemblages, which are indicative of fluid boiling, suggest that the trapping temperatures of OTii-related fluids in Central Oyu

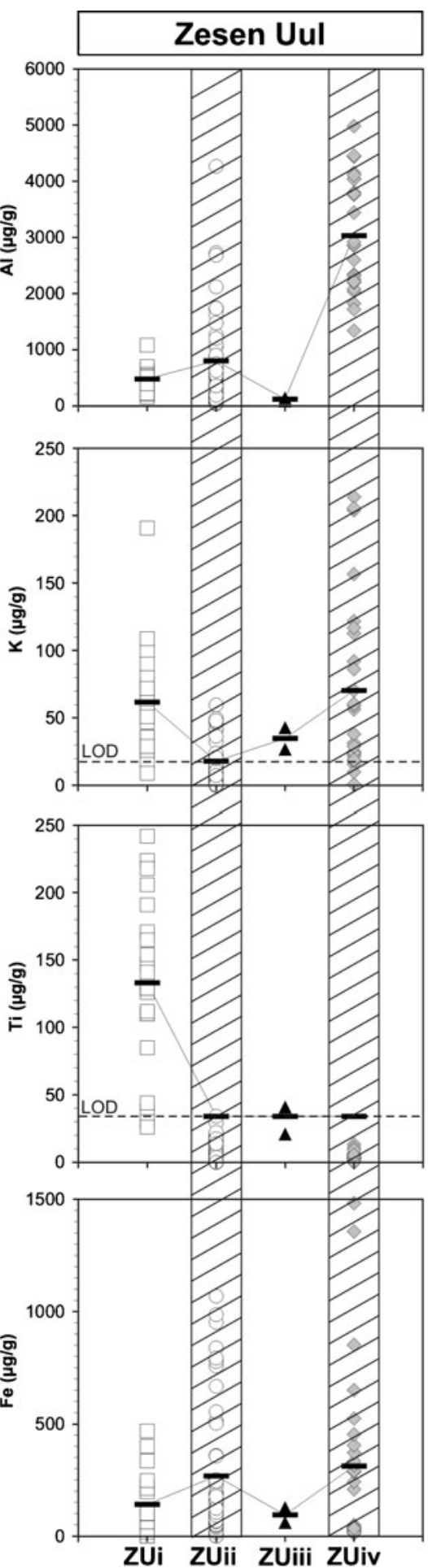

Tolgoi are similar to those determined for the ZUii-related fluids in Zesen Uul.

The OTi, OTii, ZUi and ZUii quartz generations are commonly crosscut by thin secondary fluid inclusion trails, which are healed by OTiii and ZUiii quartz indicating the inclusions are primary with respect to OTiii and ZUiii. These 
Fig. 12 Concentration diagrams of $\mathrm{Al}$ versus $\mathrm{Ti}$ and $\mathrm{Al}$ versus $\mathrm{K}$ of quartz from the stockworks of Central Oyu Tolgoi and Zesen Uul
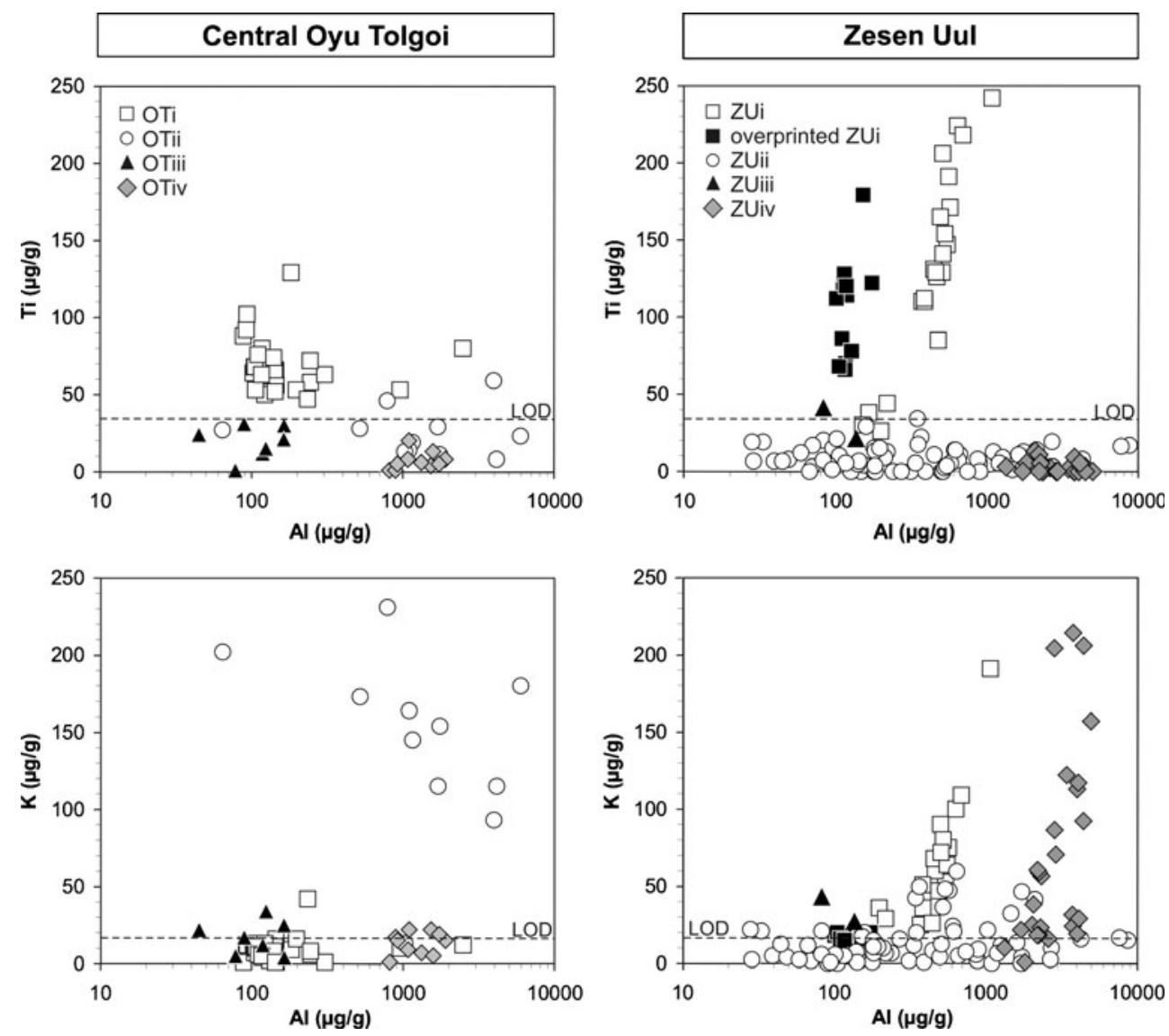

liquid-rich inclusions homogenize in the range $229^{\circ} \mathrm{C}$ to $259^{\circ}$ $\mathrm{C}$ (Central Oyu Tolgoi) and $302^{\circ} \mathrm{C}$ to $343^{\circ} \mathrm{C}$ (Zesen Uul) and have low salinities in Oyu Tolgoi and moderate salinities in Zesen Uul. Trapping temperatures were $256^{\circ} \mathrm{C}$ to $289^{\circ} \mathrm{C}$ and $335^{\circ} \mathrm{C}$ to $385^{\circ} \mathrm{C}$, respectively (Table 2 ). The few identified measurable primary liquid-rich inclusions in OTiv and ZUiv quartz have a relatively modest salinity and the OTiv and ZUiv fluids were trapped between $212^{\circ} \mathrm{C}$ and $335^{\circ} \mathrm{C}$.

Table 2 Summary of crystallisation temperature estimates for the different quartz generations based on the Ti-in-quartz geothermometer by Wark and Watson (2006) and microthermometric characteristics of fluid inclusions

\begin{tabular}{|c|c|c|c|c|c|c|c|}
\hline $\begin{array}{l}\text { Quartz } \\
\text { generation }\end{array}$ & $\begin{array}{l}\text { nr. of } \\
\text { analyses }\end{array}$ & $\begin{array}{l}\text { Ti-in-quartz thermometer } \\
\left({ }^{\circ} \mathrm{C}\right)\end{array}$ & Primary FI type & $T_{\mathrm{m}}$-ice $\left({ }^{\circ} \mathrm{C}\right)$ & $\begin{array}{l}\text { Salinity wt.\% } \mathrm{NaCl} \\
\text { eq. }\end{array}$ & $\begin{array}{l}\text { Th-tot }{ }^{\mathrm{a}} \\
\left({ }^{\circ} \mathrm{C}\right)\end{array}$ & $\begin{array}{l}T \text { trapping } \\
\left({ }^{\circ} \mathrm{C}\right)\end{array}$ \\
\hline \multicolumn{8}{|c|}{ Central Oyu Tolgoi } \\
\hline OTi & 27 (EPMA) & 653 to 792 & Glass + V & $?$ & $?$ & $>582$ & - \\
\hline OTii & 6 & - & $\mathrm{L}+\mathrm{V}+$ solids $(\mathrm{V}+\mathrm{L})$ & -20.2 to -11.2 & 15 to 22.6 & 265 to 305 & 296 to 340 \\
\hline OTiii & 3 & - & $\mathrm{L}+\mathrm{V}$ & -1.9 to -1.5 & 3 to 3.5 & 229 to 259 & 256 to 289 \\
\hline OTiv & 4 & - & $\mathrm{L}+\mathrm{V}$ & -2.5 to -1.4 & 2.8 to 4.4 & 190 to 204 & 212 to 228 \\
\hline \multicolumn{8}{|l|}{ Zesen Uul } \\
\hline ZUi & 22 (EPMA) & 598 to 880 & Glass $+\mathrm{V}$ & $?$ & $?$ & $>550$ & - \\
\hline ZUii & 5 & - & $\mathrm{L}+\mathrm{V}+$ solids $(\mathrm{V}+\mathrm{L})$ & -16.1 to -10 & $>13.9$ & 315 to 417 & 353 to 445 \\
\hline ZUiii & 3 & - & $\mathrm{L}+\mathrm{V}$ & -13.3 to -5.5 & 8.6 to 17.1 & 302 to 343 & 335 to 385 \\
\hline ZUiv & 8 & - & $\mathrm{L}+\mathrm{V}$ & -4.5 to -2.7 & 4.5 to 7.2 & 219 to 300 & 245 to 335 \\
\hline
\end{tabular}

Ti concentrations in quartz of stages OTii to OTiv and ZUii to ZUiv are below the limit of detection. The study of fluid inclusions was done on the same crystals as the CL and microprobe analyses. Trapping temperatures were calculated for $0.5 \mathrm{kbar}$ applying the temperature correction of Brown and Lamb (1989)

EPMA electron probe microanalysis

${ }^{\mathrm{a}}$ Homogenisation into liquid state 


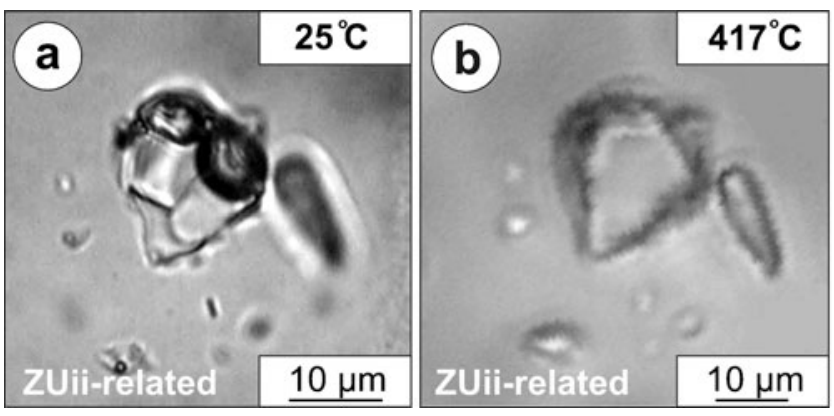

Fig. 13 Example of a primary fluid inclusion in ZUii quartz from Zesen Uul containing a vapour phase, halite, sylvite and other solids. It homogenized at $417^{\circ} \mathrm{C}$

\section{Discussion}

At Central Oyu Tolgoi and Zesen Uul, the four identified major events of quartz crystallisation have distinct trace element signatures, reflecting changes in the crystallisation temperatures, fluid chemistry variability and possibly pressure, although this latter parameter is difficult to assess. The processes that influence trace element variability in hydrothermal quartz are largely unknown, with exception of the $\mathrm{Ti}$ concentration in quartz, which can be used to calculate the crystallisation temperature (Wark and Watson 2006). Most recently, several attempts have been made by Rusk et al. (2006, 2008a) to understand the variability of $\mathrm{Al}, \mathrm{K}$ and $\mathrm{Fe}$ in quartz related to metal mineralisation. Processes that may control the incorporation of these trace elements into the quartz lattice and the related changes of P-T-X conditions are discussed in the paragraphs below.

The main characteristics of the crystallisation stages of both deposits are compared in Table 3. The data in Table 3 show that the corresponding stages 1, 2, 3 and 4 of both deposits have comparable characteristics indicating a common sequence of evolutionary stages during formation of the central stockwork. Therefore, the corresponding stages of both deposits are discussed together.

\section{Stage 1: OTi and ZUi}

During the OTi and ZUi stages, the magmatic hydrothermal fluids breach the boundary between ductile rock at lithostatic pressure and fractures in overlaying brittle rock at hydrostatic pressure, leading to intense fracturing and fluid flow. The fracturing is accompanied by a drop in pressure which may have been of the order of $0.5 \mathrm{kbar}$, from about $1 \mathrm{kbar}$ (maximum lithostatic pressure) to $0.5 \mathrm{kbar}$ in the case of Central Oyu Tolgoi (Perelló et al. 2001). The solubility of quartz decreases with decreasing pressure at temperatures of $720^{\circ} \mathrm{C}$ from 3,600 to $1,000 \mathrm{mg} /$ $\mathrm{kg}$ (Fig. 14a). It is most likely that OTi and ZUi quartz precipitated when pressure dropped from lithostatic to near hydrostatic pressure accompanied by a moderate decrease in temperature (Fig. 14). As a result of the enormous volume of crystallised OTi and ZUi quartz, the ore metal contents of the hydrothermal fluid increased during the subsequent crystallisation stages, more specifically, up to OTii and ZUii formation.

Formation temperatures for OTi and ZUi were calculated applying the Ti-in-quartz geothermometer proposed by Wark and Watson (2006; Table 2). The $\mathrm{TiO}_{2}$ activity is difficult to determine; however, the OTi and ZUi quartzdepositing fluids originated from intermediate magmas, which were most likely $\mathrm{TiO}_{2}$ saturated, and from which rutile is likely to have crystallised. The crystallisation temperatures calculated were in the range $653^{\circ} \mathrm{C}$ to $792^{\circ} \mathrm{C}$ for the OTi quartz and $598^{\circ} \mathrm{C}$ to $880^{\circ} \mathrm{C}$ for the ZUi quartz. The maximum crystallisation temperature calculated for ZUi is almost $100^{\circ} \mathrm{C}$ higher than for OTi. Such high formation temperatures are consistent with early formed Atype veins reported from other porphyry copper systems (e. g. Bodnar 1995; Harris et al. 2003; Landtwing and Pettke 2005; Rusk et al. 2006, 2008a). Ti concentrations in the overprinted and homogenized $\mathrm{ZUi}$ quartz indicate temperatures in the range $700^{\circ} \mathrm{C}$ to $822^{\circ} \mathrm{C}$, which corresponds to the formation temperature of $\mathrm{ZUi}$ quartz.

The relatively low average $\mathrm{Al}$ and $\mathrm{K}$ in OTi and ZUi quartz compared to concentrations published for hydrothermal quartz (e.g. Perny et al. 1992; Jourdan et al. 2009) presumably indicates that $\mathrm{Al}$ and $\mathrm{K}$ complexes in the hot magma-derived fluids preferred to precipitate as K-feldspar in the wall rock, incorporating $\mathrm{Al}$ and $\mathrm{K}$ that might have otherwise entered the quartz lattice.

\section{Stage 2: OTii and ZUii}

The micro-textures of OTii and ZUii quartz revealed by $\mathrm{CL}$ can be best explained by dissolution of pre-existing OTi and ZUi quartz and precipitation of new, weakly luminescent OTii and ZUii quartz. The quartz precipitated during the OTii and ZUii stages contains fine-grained inclusions of both pyrite and chalcopyrite and is intergrown with pyrite and chalcopyrite crystals. This suggests that OTii and ZUii accompanied the main sulphide mineralisation. In Zesen Uul, comb-like ZUii crystals showing oscillatory zoning are common, whereas they are rare in OTii Central Oyu Tolgoi.

The observed dissolution features relate to cooling of the hydrothermal system through and beyond the interval of retrograde quartz solubility (Fig. 14). During cooling of the hydrothermal system from $540^{\circ} \mathrm{C}$ to $400^{\circ} \mathrm{C}$ (Central Oyu Tolgoi) and $575^{\circ} \mathrm{C}$ to $450^{\circ} \mathrm{C}$ (Zesen Uul), the OTi and ZUi quartz partially dissolved and OTii and ZUii quartz began to precipitate at $<400^{\circ} \mathrm{C}$ and $<450^{\circ} \mathrm{C}$, respectively, into the newly created pore space. The maximum fluid trapping 
Table 3 Comparison of the characteristics of the major crystallisation stages found in the Central Oyu Tolgoi and Zesen Uul deposits

\begin{tabular}{|c|c|c|c|c|c|}
\hline \multirow{2}{*}{$\begin{array}{l}\text { Stage } \\
1\end{array}$} & \multirow{2}{*}{$\begin{array}{l}\text { Characteristics } \\
\text { CL intensity }\end{array}$} & \multicolumn{2}{|c|}{ Central Oyu Tolgoi } & \multicolumn{2}{|c|}{ Zesen Uul } \\
\hline & & OTi & High & ZUi & High \\
\hline & CL structures & & Oscillatory zoning & & Oscillatory zoning \\
\hline & Temperature & & $653^{\circ} \mathrm{C}$ to $792^{\circ} \mathrm{C}$ & & $598^{\circ} \mathrm{C}$ to $880^{\circ} \mathrm{C}$ \\
\hline & Fluid salinity & & $?$ & & $?$ \\
\hline & Average Al & & $263 \mu \mathrm{g} \mathrm{g}^{-1}$ & & $470 \mu \mathrm{g} \mathrm{g}^{-1}$ \\
\hline & Average Ti & & $69 \mu \mathrm{g} \mathrm{g}^{-1}$ & & $133 \mu \mathrm{g} \mathrm{g}^{-1}$ \\
\hline & Average K & & $<18 \mu \mathrm{g} \quad \mathrm{g}^{-1}$ & & $62 \mu \mathrm{g} \mathrm{g}^{-1}$ \\
\hline & Average $\mathrm{Fe}$ & & $125 \mu \mathrm{g} \mathrm{g}^{-1}$ & & $141 \mu \mathrm{g} \mathrm{g}^{-1}$ \\
\hline & Associated sulphides & & py, ccp, mo & & py, ccp \\
\hline \multirow[t]{9}{*}{2} & CL intensity & OTii & Low & ZUii & Low \\
\hline & CL structures & & Wavy structures & & Oscillatory and sector zoning \\
\hline & Temperature & & $296^{\circ} \mathrm{C}$ to $340^{\circ} \mathrm{C}$ & & $353^{\circ} \mathrm{C}$ to $445^{\circ} \mathrm{C}$ \\
\hline & Fluid salinity & & 15 to 22.6 wt. $\% \mathrm{NaCl}$ eq. & & $>13.9$ wt. $\% \mathrm{NaCl}$ eq. \\
\hline & Average Al & & $2,011 \mu \mathrm{g} \quad \mathrm{g}^{-1}$ & & $795 \mu \mathrm{g} \mathrm{g}^{-1}$ \\
\hline & Average Ti & & $<34 \mu \mathrm{g} \mathrm{g}^{-1}$ & & $<34 \mu \mathrm{g} \mathrm{g}^{-1}$ \\
\hline & Average K & & $144 \mu \mathrm{g} \quad \mathrm{g}^{-1}$ & & $<18 \mu \mathrm{g} \quad \mathrm{g}^{-1}$ \\
\hline & Average $\mathrm{Fe}$ & & $64 \mu \mathrm{g} \mathrm{g}^{-1}$ & & $267 \mu \mathrm{g} \mathrm{g}^{-1}$ \\
\hline & Associated sulphides & & No & & No \\
\hline \multirow[t]{9}{*}{3} & CL intensity & OTiii & Low & ZUiii & Low \\
\hline & CL structures & & No & & No \\
\hline & Temperature & & $256^{\circ} \mathrm{C}$ to $289^{\circ} \mathrm{C}$ & & $335^{\circ} \mathrm{C}$ to $385^{\circ} \mathrm{C}$ \\
\hline & Fluid salinity & & 3 to 3.5 wt. $\% \mathrm{NaCl}$ eq. & & 8.6 to 17.1 wt. $\% \mathrm{NaCl}$ eq. \\
\hline & Average Al & & $112 \mu \mathrm{g} \mathrm{g}^{-1}$ & & $110 \mu \mathrm{g} \quad \mathrm{g}^{-1}$ \\
\hline & Average Ti & & $<34 \mu \mathrm{g} \quad \mathrm{g}^{-1}$ & & $<34 \mu \mathrm{g} \quad \mathrm{g}^{-1}$ \\
\hline & Average K & & $<18 \mu \mathrm{g} \mathrm{g}^{-1}$ & & $35 \mu \mathrm{g} \mathrm{g}^{-1}$ \\
\hline & Average $\mathrm{Fe}$ & & $88 \mu \mathrm{g} \mathrm{g}^{-1}$ & & $94 \mu \mathrm{g} \mathrm{g}^{-1}$ \\
\hline & Associated sulphides & & No & & No \\
\hline \multirow[t]{9}{*}{4} & CL intensity & OTiv & Low & ZUiv & Low \\
\hline & CL structures & & No & & No \\
\hline & Temperature & & $212^{\circ} \mathrm{C}$ to $228^{\circ} \mathrm{C}$ & & $245^{\circ} \mathrm{C}$ to $335^{\circ} \mathrm{C}$ \\
\hline & Fluid salinity & & 2.8 to 4.4 wt. $\% \mathrm{NaCl}$ eq. & & 4.5 to 7.2 wt. $\% \mathrm{NaCl}$ eq. \\
\hline & Average Al & & $1,285 \mu \mathrm{g} \quad \mathrm{g}^{-1}$ & & $3,024 \mu \mathrm{g} \quad \mathrm{g}^{-1}$ \\
\hline & Average Ti & & $<34 \mu \mathrm{g} \mathrm{g}^{-1}$ & & $<34 \mu \mathrm{g} \mathrm{g} \mathrm{g}^{-1}$ \\
\hline & Average K & & $<18 \mu \mathrm{g} \mathrm{g}^{-1}$ & & $70 \mu \mathrm{g} \mathrm{g}^{-1}$ \\
\hline & Average $\mathrm{Fe}$ & & $186 \mu \mathrm{g} \quad \mathrm{g}^{-1}$ & & $311 \mu \mathrm{g} \mathrm{g}^{-1}$ \\
\hline & Associated sulphides & & No & & $\mathrm{cv}, \mathrm{bs}$ \\
\hline
\end{tabular}

Trace element concentrations of relic OTi quartz in OTii structures and of overprinted OTiv and ZUi quartz are not considered in the average values (see Table 1)

$c c p$ chalcopyrite, $c v$ covellite, $b s$ bismuthinite, mo molybdenite, $p y$ pyrite

temperature of ZUii quartz of $445^{\circ} \mathrm{C}$ indicates that the hydrostatic pressure was up to $0.7 \mathrm{kbar}$ at Zesen Uul (Fig. 14b). Rusk and Reed (2002) made similar textural observations on quartz veins of the Butte porphyry deposit, Montana, explaining the quartz dissolution in terms of fluid cooling from $550^{\circ} \mathrm{C}$ to $470^{\circ} \mathrm{C}$ at pressures of about $0.7 \mathrm{kbar}$. Under these conditions, the fluid cooled through the interval of retrograde quartz solubility (Fig. 14).
The distinct drop in concentration of $\mathrm{Ti}$ in quartz between OTi and OTii and between ZUi and ZUii reflects the significant decrease in the quartz crystallisation temperature of $>180^{\circ} \mathrm{C}$ established by the fluid inclusion studies. The temperature decrease is more significant in the Central Oyu Tolgoi samples.

The high average and variable $\mathrm{Al}$ in OTii and ZUii quartz may reflect the concentration of the ionised $\mathrm{Al}$ in the 

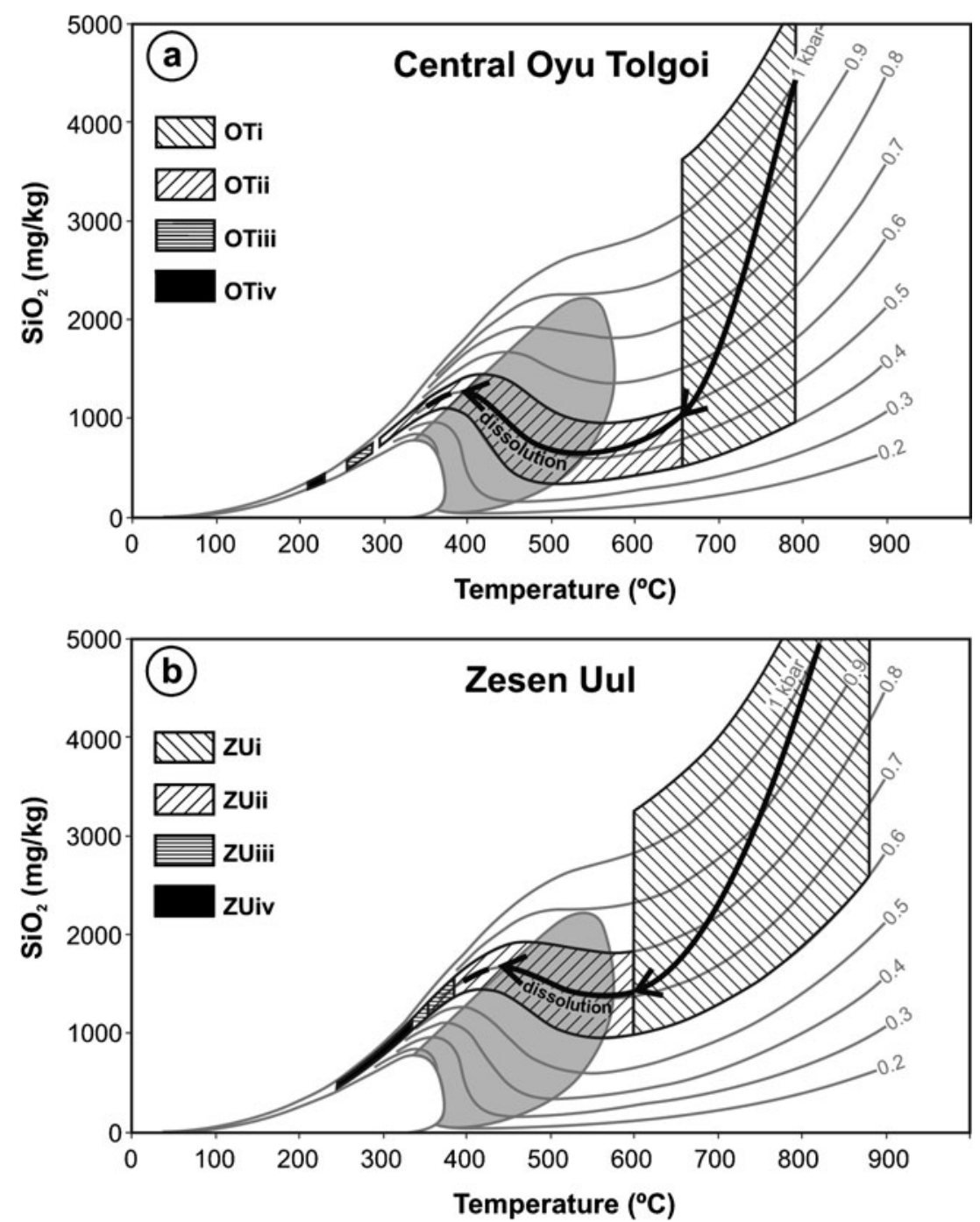

Fig. 14 Calculated solubilities of quartz in pure water up to $900^{\circ} \mathrm{C}$ at the indicated pressures according to Fournier (1985). The shaded area emphasizes the region of retrograde quartz solubility. The temperature-pressure field of retrograde quartz solubility shifts to slightly higher temperatures with increasing salinity (Fournier 1985); however, complete data for different salinities in the shown temperature and pressure range are not available. a Quartz of the OTi stage precipitated during pressure drop from lithostatic $(\sim 1 \mathrm{kbar})$ to near hydrostatic pressure ( 0.5 kbar) accompanied by a moderate decrease in

hydrothermal fluid, which is strongly dependent on fluid temperature and $\mathrm{pH}$ (Pokrovskii and Helgeson 1995). The solubility of $\mathrm{Al}$ increases with decreasing $\mathrm{pH}$. The increase of acidity of the hydrothermal fluids from the OTi and ZUi stages to the OTii and ZUii stages is indicated by the OTii and ZUii mineral assemblages (Figs. 4 and 6; e.g. Beane and Bodnar 1995). Acidic pHs are commonly observed at this evolutionary stage of porphyry systems (e.g. Heinrich 2005), providing the $\mathrm{H}^{+}$necessary for ionisation of $\mathrm{Al}$. It appears that the variations of $\mathrm{Al}$ in OTii and ZUii may result from fluctuations of the fluid $\mathrm{pH}$ during the crystallisation of OTii and ZUii quartz, which is in temperature in the range of $792^{\circ} \mathrm{C}$ to $653^{\circ} \mathrm{C}$. OTi quartz was partially dissolved during cooling of the hydrothermal system from $540^{\circ} \mathrm{C}$ down to $400^{\circ} \mathrm{C}$. OTii quartz precipitated at temperatures $<400^{\circ} \mathrm{C}$ into the newly created pore space. b Quartz of the ZUi stage precipitated during decreasing pressure from about 1 to $0.7 \mathrm{kbar}$ accompanied by a decrease in temperature in the range of $880^{\circ} \mathrm{C}$ to $598^{\circ} \mathrm{C}$. ZUi quartz was partially dissolved during cooling of the hydrothermal system from $575^{\circ} \mathrm{C}$ to $450^{\circ} \mathrm{C}$. ZUii quartz precipitated at temperatures $<450^{\circ}$ $\mathrm{C}$ into the newly created pore space

accordance with observations made by Rusk et al. (2008a) in porphyry and epithermal deposits.

The high Al of the OTii quartz of Central Oyu Tolgoi correlates with high $\mathrm{K}$ values whereas the $\mathrm{K}$ content in ZUii quartz from Zesen Uul is much lower. This result indicates that the $\mathrm{K}$ concentration in quartz only partially follows the pattern of the $\mathrm{Al}$ concentration. The incorporation of $\mathrm{K}$ into the ZUii quartz of Zesen Uul is presumably accompanied by inclusion of other ions to preserve charge balance.

Several high Fe concentrations were detected in the quartz of the OTii and ZUii stages close to sulphide minerals, a phenomenon observed by Penniston-Dorland (2001) in the 
Grasberg porphyry, Indonesia. These high values are interpreted as being caused by post-crystallisation diffusion of $\mathrm{Fe}^{2+}$ from $\mathrm{Fe}$-sulphides into the quartz lattice (Fig. 10d) and are not a primary feature of the ZUii. $\mathrm{Fe}^{2+}$ is a CL quenching ion (Marshall 1988) resulting in depression of the quartz CL close to sulphides (Fig. 8d). Penniston-Dorland (2001) pointed out that the diffusion coefficient of $\mathrm{Fe}$ in quartz is probably much higher than $10^{12} \mathrm{~cm}^{2} \mathrm{~s}^{-1}$, and thus, $\mathrm{Fe}^{2+}$ easily migrates into quartz.

The determined P-T-X conditions of the OTii and ZUii stage at Central Oyu Tolgoi and Zesen Uul are comparable to conditions recorded for the main ore stage from the Bingham and Butte porphyries, USA (Redmond et al. 2004; Landtwing et al. 2005; Rusk et al. 2008b).

\section{Stage 3: OTiii and ZUiii}

The OTiii and ZUiii quartz formed during widespread micro-veining and subsequent crack healing (Figs. $8 \mathrm{c}$ and 9e). Similar textures are commonly observed not only in quartz of porphyry systems (e.g. Rusk and Reed 2002) but also in igneous quartz of felsic plutonic and subvolcanic rocks (e.g. Sprunt and Nur 1979; Valley and Graham 1996; Müller et al. 2000). The origin of the OTiii and ZUiii quartz-forming fluids with low (Central Oyu Tolgoi) and moderate (Zesen Uul) salinities is not clearly defined.

\section{Stage 4: OTiv and ZUiv}

The OTiv- and ZUiv-calcite micro-breccia veins penetrating the A-type veins carry minor sulphide mineralisation (Fig. 8f). These late veinlets are similar to widespread calcite-rich veins precipitated during the same late stage in other porphyry systems (e.g. Seedorff et al. 2005), but only rarely described in the literature (e.g. Armstrong and Willan 1996). The high Al contents of OTiv and ZUiv quartz may have resulted from the moderate acidity of the OTiv and ZUiv quartz-forming fluids, leading to the same increase in $\mathrm{Al}$ as discussed for the OTii and ZUii stages. High K concentrations are characteristic for ZUiv quartz at Zesen Uul only. The early magmatic fluids of the Zesen Uul system are relatively poor in $\mathrm{K}$, as indicated by the absence of K-feldspar or biotite alteration associated with early stage quartz. Thus, the enrichment of $\mathrm{K}$ in the ZUiv quartz may be indicative of alkali enrichment of the fluids due to an increasing interaction with the host rocks. The moderate to high Fe content of the OTiv and ZUiv quartz is presumably of primary origin as EPMA analyses carried out at least $500 \mu \mathrm{m}$ from any Fe-rich minerals commonly show elevated $\mathrm{Fe}$ concentrations, excluding the phenomenon of $\mathrm{Fe}$ enrichment by diffusion as observed in OTii and ZUii quartz. The elevated Fe concentrations in OTiv and ZUiv quartz maybe caused by the increasing ionisation of $\mathrm{Fe}$ complexes in the hydrothermal fluid due to decreasing fluid salinity and temperature (Hemley et al. 1992).

\section{Summary}

The investigated A-type veins, which are considered to have formed during the early stage of stockwork formation, show complex growth structures with multiple overprinting and replacement revealed by CL imaging. CL imaging combined with high-resolution trace element analysis and fluid inclusion data assists in the reconstruction of deposit formation, helping to decipher the thermal and chemical evolution of transitional magmatic-hydrothermal systems. This combined approach reveals the chronological relationships of quartz precipitation and dissolution stages with respect to ore mineralisation.

The Central Oyu Tolgoi and Zesen Uul Cu-Au porphyry systems differ in age and are separated by more than $100 \mathrm{~km}$ and show differences in their alteration and mineralisation styles; despite this, a common sequence of evolutionary stages has been demonstrated by this study. Four similar major quartz crystallisation stages were identified in the central mineralised stockworks of the Central Oyu Tolgoi (OTi to OTiv) and Zesen Uul deposits (ZUi and ZUiv), namely:

1. OTi and ZUi quartz occurs in barren A-type veins and as massive silicification of the host rocks. OTi and ZUi quartz is brightly luminescent with high Ti contents, indicative of crystallisation temperatures greater than $600^{\circ} \mathrm{C}$. This quartz stage forms more than 90 vol.\% of the quartz mass of the stockworks in each deposit.

2. OTii and ZUii stage structures are mineralised, comprising dull luminescent quartz with high and variable $\mathrm{Al}$ contents together with high $\mathrm{K}$ values in places. OTii and ZUii quartz precipitated from a fluid with a low but fluctuating $\mathrm{pH}$. This onset of high and variable $\mathrm{Al}$ in quartz is indicative of the onset of sulphide mineralisation.

3. OTiii and ZUiii structures are largely barren of mineralisation and comprise dull to non-luminescent quartz with low $\mathrm{Ti}, \mathrm{Al}, \mathrm{K}$ and $\mathrm{Fe}$ contents. OTiii and ZUiii stage fluids had moderate salinities.

4. OTiv and ZUiv formed dull luminescent quartz with high and variable $\mathrm{Al}$ and $\mathrm{Fe}$ contents hosted in calcite vein breccias which in places have associated sulphides.

The distinct trace element signature of each of the individual quartz generation reflects the variability of fluid temperature and acidity at different stages of the evolution of the magmatic-hydrothermal system. 
CL patterns and related trace element variations seen in this study of the Mongolian porphyries appear identical to those described recently from other porphyry systems (e.g. Penniston-Dorland 2001; Rusk and Reed 2002; Landtwing and Pettke 2005; Redmond et al. 2004; Rusk et al. 2006, 2008a), despite major differences in age of formation and geological setting. Just as paragenetic studies have long revealed consistent sequences of overprinting vein assemblages, trace element and textural studies of quartz, revealed by EPMA and CL, appear to support the idea that a common sequence of quartz crystallisation exists at least for the earliest vein stages (OTi to OTiii and ZUi to ZUiii). Detailed understanding of the strongly heterogeneous distribution of trace elements within a paragenetically complex series of quartz generations assists in understanding the processes involved in the early evolution and mineralisation in porphyry copper systems.

Acknowledgements We thank the management of Ivanhoe Mines Ltd. Mongolia for the financial support of the project and for providing the drill core samples. This work was also supported by the Deutsche Forschungsgemeinschaft (MU 1717/2-1), the Natural History Museum of London and the Geological Survey of Norway. We are grateful to Chris Stanley for discussions and suggestions. We appreciated the constructive reviews by Tim Baker, Anthony Harris and Noel White which improved the quality of the manuscript considerably.

\section{References}

Arancibia ON, Clark AH (1996) Early magnetite-amphibole-plagioclase alteration-mineralization in the Island Copper porphyry copper-gold-molybdenum deposit, British Columbia. Econ Geol 91:402-438

Armstrong DC, Willan RCR (1996) Orthomagmatic quartz and postmagmatic carbonate veins in a reported porphyry copper deposit, Andean intrusive suite, Livingston Island, South Shetland Islands. Miner Deposita 31:290-306

Badarch G, Cunningham DW, Windley BF (2002) A new terrane subdivision for Mongolia: implications for the Phanerozoic crustal growth of Central Asia. J Asian Earth Sc 21:87-110

Beane RE, Bodnar RJ (1995) Hydrothermal fluids and hydrothermal alteration in porphyry copper deposits. In: Pierce FW, Bohm JG (eds) Porphyry copper deposits of the American Cordillera. Arizona Geol Soc Digest 20, Tucson, pp 83-93

Bodnar RJ (1995) Fluid-inclusion evidence for magmatic source for metals in porphyry copper deposits. In: Thompson JFH (ed) Magmas, fluids, and ore deposits. Mineralogical Association of Canada, Short Course Series vol. 23. Mineralogical Association of Canada, Ottawa, pp 139-152

Brown PE, Lamb WM (1989) P-V-T properties of fluids in the system $\mathrm{H}_{2} \mathrm{O} \pm \mathrm{CO}_{2} \pm \mathrm{NaCl}$. New graphical presentations and implications for fluid inclusion studies. Geochim Cosmochim Acta 53:1209-1221

Candela PA, Piccoli PM (1995) Model ore-metal partitioning from melts into vapor and vapor/brine mixtures. In: Thompson JFH (ed) Magmas, fluids, and ore deposits. Mineralogical Association of Canada, Short Course Series Vol. 23. Mineralogical Association of Canada, Ottawa, pp 101-127
Carten RB, Geraghty EP, Walker BM, Shannon JR (1988) Cyclic development of igneous features and their relationship to high-temperature hydrothermal features in the Henderson porphyry molybdenum deposit, Colorado. Econ Geol 83:266-296

Demars C, Pagel M, Deloule E, Blanc P (1996) Cathodoluminescence of quartz from sandstones: Interpretation of the UV range by determination of trace element distributions and fluid-inclusion P-T-X properties in authigenic quartz. Am Mineral 81:891-901

Dilles JH, Einaudi MT (1992) Wall-rock alteration and hydrothermal flow paths about the Ann-Mason porphyry copper deposit, Nevada-a $6 \mathrm{~km}$ vertical reconstruction. Econ Geol 87:19632001

Forster CN, Kirwin DJ, Kavalieris I, Crane D, Orssich C, Panther C, Garamjav D, Munkhbat TO, Niislelkhuu G (2003) Recent advances in the understanding of the geology and mineralisation of the Oyu Tolgoi copper-gold porphyry deposits, south Gobi, Mongolia. Mongolian Geoscientist 21:36

Fournier RO (1985) The behavior of silica in hydrothermal solutions. In: Berger BR, Bethke PM (eds) Geology and geochemistry of epithermal systems. Rev Econ Geol Vol. 2. Society of Economic Geologists, Littleton, pp 45-61

Fournier RO (1999) Hydrothermal processes related to movement of fluid from plastic to brittle rock in the magmatic-epithermal environment. Econ Geol 94:1193-1211

Gerel O (1995) Mineral resources of the western part of the MongolOkhotsk fold belt. Resour Geol Spec Issue 18:151-157

Gerel O (1998) Phanerozoic felsic magmatism and related mineralisation in Mongolia. Bull Geol Surv Jpn 49:239-248

Götze J, Plötze M, Habermann D (2001) Origin, spectral characteristics and practical applications of the cathodoluminescence (CL) of quartz-a review. Min Pet 71:225-250

Guilbert JM, Lowell JD (1974) Variations in zoning patterns in porphyry ore deposits. Can Min Metall Bull 67(742):99-109

Gustafson LB, Hunt JP (1975) The porphyry copper deposit at El Salvador, Chile. Econ Geol 70:857-912

Harris AC, Golding SD (2002) New evidence of magmatic-fluidrelated phyllic alteration: implications for the genesis of porphyry $\mathrm{Cu}$ deposits. Geology 30:335-338

Harris AC, Kamenetsky VS, White NC, van Achterbergh E, Ryan CG (2003) Melt inclusions in veins: linking magmas and porphyry $\mathrm{Cu}$ deposits. Science 302:2109-2111

Hedenquist JW, Lowenstern JB (1994) The role of magmas in the formation of hydrothermal ore deposits. Nature 370:519-527

Heinrich CA (2005) The physical and chemical evolution of lowsalinity magmatic fluids at the porphyry to epithermal transition: a thermodynamic study. Miner Deposita 39:864-889

Hemley JJ, Cygan GL, Fein JB, Robinson GR, D'Angelo WM (1992) Hydrothermal ore-forming processes in the light of studies in rock-buffered systems: I. Iron-copper-zinc-lead sulphide solubility relations. Econ Geol 87:1-22

Ivanhoe Mines (2008) Mongolia projects. http://www.ivanhoe-mines. com/s/Home.asp. Accessed 20th May 2008

Jargalsaihan D (1996) Mineral resources of Mongolia. In: Jargalsaihan D, Kazmer M, Baras Z, Sanjaadorj D (eds) Guide to the geology and mineral resources of Mongolia. Geological Exploration, Consulting and Services, Ulaanbaatar, pp 111-221

Jourdan A-L, Vennemann TW, Mullis J, Ramseyer K, Spiers CJ (2009) Evidence of growth and sector zoning in hydrothermal quartz from Alpine veins. Eur J Mineral 21:219-231

Khashgerel B-E, Kavalieris I, Hayashi K-I (2008) Mineralogy, textures, and whole-rock geochemistry of advanced argillic alteration: Hugo Dummett porphyry $\mathrm{Cu}-\mathrm{Au}$ deposit, Oyu Tolgoi mineral district, Mongolia. Miner Deposita 43:913-932

Kirwin DJ, Forster CN, Garamjav D (2003) The discovery history of the Oyu Tolgoi porphyry copper-gold deposit, South Gobi, 
Mongolia. Proc. NewGenGold 2003 Conference, Perth, WA, pp 130-146

Kirwin DJ, Forster CN, Kavalieris I, Crane D, Orssich C, Panther C, Garamjav D, Munkhbat TO, Niislelkhuu G (2005a) The Oyu Tolgoi copper-gold porphyry deposits, south Gobi, Mongolia. In: Seltmann R, Gerel O, Kirwin DJ (eds) Geodynamics and metallogeny of Mongolia with a special emphasis on copper and gold deposits. SEG-IAGOD field trip, 14-16 August 2005, 8th biennial SGA meeting. IAGOD Guidebook Series 11. CERCAMS/NHM, London, pp 155-168

Kirwin DJ, Wilson CC, Turmagnai D, Wolfe R (2005b) Exploration history, geology, and mineralisation of the Kharmagtai goldcopper porphyry district, South Gobi region, Mongolia. In: Seltmann R, Gerel O, Kirwin DJ (eds) Geodynamics and metallogeny of Mongolia with a special emphasis on copper and gold deposits. SEG-IAGOD field trip, 14-16 August 2005, 8th biennial SGA meeting. IAGOD Guidebook Series 11. CERCAMS/NHM, London, pp 175-191

Landtwing MR, Pettke T (2005) Relationships between SEMcathodoluminescence response and trace-element composition of hydrothermal vein quartz. Am Mineral 90:122-131

Landtwing MR, Pettke T, Halter WE, Heinrich CA, Redmond PB, Einaudi MT, Kunze K (2005) Copper deposition during quartz dissolution by cooling magmatic-hydrothermal fluids: the Bingham porphyry. Earth Planet Sci Lett 235:229-243

Marshall DJ (1988) Cathodoluminescence of geological materials. Unwin Hyman, Boston

Müller A, Seltmann R, Behr H-J (2000) Application of cathodoluminescence to magmatic quartz in a tin granite - case study from the Schellerhau Granite Complex, Eastern Erzgebirge, Germany. Miner Deposita 35:169-189

Müller A, Lennox P, Trzebski R (2002) Cathodoluminescence and micro-structural evidence for crystallisation and deformation processes of granites in the Eastern Lachlan Fold Belt (SE Australia). Contrib Mineral Petrol 143:510-524

Müller A, Armstrong R, Herrington R, Seltmann R (2003) Characterisation of quartz textures in porphyry copper ore deposits by scanning electron microscope-cathodoluminescence (SEM-CL). Mongolian Geoscientist 21:32-35

Penniston-Dorland SC (2001) Illumination of vein quartz textures in a porphyry copper ore deposits using scanned cathodoluminescence: Grasberg Igneous Complex, Irian Jaya, Indonesia. Am Mineral 86:652-666

Perelló J, Cox D, Garamjav D, Sanjdorj S, Diakov S, Schissel D, Munkhbat T-O, Oyun G (2001) Oyu Tolgoi, Mongolia: Siluro-Devonian porphyry $\mathrm{Cu}-\mathrm{Au}-(\mathrm{Mo})$ and high-sulfidation $\mathrm{Cu}$ mineralisation with a Cretaceous chalcocite blanket. Econ Geol 96:1407-1428

Perny B, Eberhardt P, Ramseyer K, Mullis J, Pankrath R (1992) Microdistribution of $\mathrm{Al}, \mathrm{Li}$, and $\mathrm{Na}$ in $\alpha$-quartz: possible causes and correlation with short-lived cathodoluminescence. Am Mineral 77:534-544

Pollard PJ, Taylor RG (2002) Observations on the nature, associations and paragenetic positioning of gold within selected samples from the Kharmagtai and $\mathrm{OV} 3 \mathrm{Cu}-\mathrm{Au}$ deposits, South Gobi region Mongolia. Report to Ivanhoe Mines Ltd. (unpubl.)
Proffett JM (2003) Geology of the Bajo de la Alumbrera porphyry copper-gold deposit, Argentina. Econ Geol 98:1535-1574

Pokrovskii VA, Helgeson HC (1995) Thermodynamic properties of aqueous species and the solubilities of minerals at high pressures and temperatures: the system $\mathrm{Al}_{2} \mathrm{O}_{3}-\mathrm{H}_{2} \mathrm{O}-\mathrm{NaCl}$. Am J Sci 295:1255-1342

Redmond PB, Einaudi MT, Inan EE, Landtwing MR, Heinrich CA (2004) Copper deposition by fluid cooling in intrusion-centered systems: new insights from the Bingham porphyry ore deposit, Utah. Geology 32:217-220

Rusk BG, Reed M (2002) Scanning electron microscope-cathodoluminescence analysis of quartz reveals complex growth histories in veins from the Butte porphyry copper deposit, Montana. Geology 30:727-730

Rusk BG, Reed MH, Dilles JH, Kent AJR (2006) Intensity of quartz cathodoluminescence and trace element content in quartz from the porphyry copper deposit at Butte, Montana. Am Mineral 91:1300-1312

Rusk BG, Lowers HA, Reed MH (2008a) Trace elements in hydrothermal quartz: relationships to cathodoluminescence textures and insights into vein formation. Geology 36:547-550

Rusk BG, Reed MH, Dilles JH (2008b) Fluid inclusion evidence for magmatic-hydrothermal fluid evolution in the porphyry coppermolybdenum deposit at Butte, Montana. Econ Geol 103:307-334

Seedorff E, Dilles JH, Proffett JM Jr, Einaudi MT, Zurcher L, Stavast WJA, Johnson DA, Barton MD (2005) Porphyry deposits: characteristics and origin of hypogene features. In: Hedenquist JW, Thompson JFH, Goldfarb RJ, Richards JP (eds) Economic Geology 100th Anniversary volume. Society of Economic Geologists, Littleton, pp 251-298

Seltmann R, Porter TM (2005) The porphyry $\mathrm{Cu}-\mathrm{Au} / \mathrm{Mo}$ deposits of central Eurasia. 1. Tectonic, geologic and metallogenetic setting and significant deposits. In: Porter TM (ed) Super porphyry copper and gold deposits: a global perspective, vol 2. PGC, Adelaide, pp 467-512

Sprunt ES, Nur A (1979) Microcracking and healing in granites: new evidence from cathodoluminescence. Science 205:496-497

Stevens-Kalceff MA, Phillips MR (1995) Cathodoluminescence microcharacterization of the defect structure of quartz. Phys Rev B 52:3122-3134

Valley JW, Graham CM (1996) Ion microprobe analysis of oxygen isotope ratios in quartz from Skye granite: healed micro-cracks, fluid flow, and hydrothermal exchange. Contrib Mineral Petrol 124:225-234

Wainwright AJ, Tosdal RM, Forster C, Kavalieris I, Crane D, Findlay A, Kirwin D (2004) Structure and stratigraphy of the Oyu Tolgoi $\mathrm{Cu}-\mathrm{Au}$ porphyry, Mongolia. Poster, Cordilleran Roundup 2004, http://www.mdru.ubc.ca/home/research/hd-ot-roundup 04 poster.pdf. Accessed 20 May 2008

Wark DA, Spear FS (2005) Titanium in quartz: cathodoluminescence and thermometry. Geochim Cosmochim Acta Suppl 69:A592

Wark DA, Watson EB (2006) TitaniQ: a titanium-in-quartz geothermometer. Contrib Mineral Petrol 152:743-754

Wilkinson JJ (2001) Fluid inclusions in hydrothermal ore deposits. Lithos 55:229-272 